\title{
Türk Nefroloji, Diyaliz ve Transplantasyon Hemşireleri Derneği COVID-19 Komisyonu COVID-19 Koronavirüs Hastalığı Rehberleri
}

\author{
The COVID-19 Coronavirus Disease Guidelines of the \\ COVID - 19 Commission of Turkish Nephrology, Dialysis, \\ and Transplantation Nurses Association
}

Ayten KARAKOÇ ${ }^{1}$, Nermin ERDOĞ ${ }^{2}{ }^{2}$, Yaprak SARIGÖL ORDİN ${ }^{3}$, Güler NASUHBEYOĞLU ${ }^{4}$, Fatma ERSOY ${ }^{5}$, Gülseren PEHLIVAN ${ }^{6}$, Sevel YILDIZ ${ }^{7}$, Sevginar ŞENTÜRK ${ }^{8}$

${ }^{1}$ Uzm. Hemşire, SBÜ İstanbul Bakırköy Dr. Sadi Konuk Eğitim Araştırma Hastanesi Diyaliz Ünitesi, İstanbul, Türkiye

${ }^{2}$ Uzm. Hemşire, İstanbul Koç Diyaliz Merkezleri Grubu, İstanbul, Türkiye

${ }^{3}$ Doç.Dr., Dokuz Eylül Üniversitesi Hemşirelik Fakültesi, Cerrahi Hastalıklar Hemşireliği AD, İzmir, Türkiye

${ }^{4}$ Hemşire, Dokuz Eylül Üniversitesi Hastanesi Diyaliz Ünitesi, İzmir, Türkiye

${ }^{5}$ Hemşire, FMC Antalya Özel Diyaliz Merkezi, Antalya, Türkiye

${ }^{6}$ Hemşire, İstanbul Üniversitesi Cerrahpaşa Tıp Fakültesi Hastanesi Diyaliz Ünitesi, İstanbul, Türkiye

${ }^{7}$ Hemşire, İstanbul Üniversitesi Çapa Tıp Fakültesi Hastanesi Diyaliz Ünitesi, İstanbul, Türkiye

${ }^{8}$ Hemşire, Sağlık Bilimleri Üniversitesi İzmir Tepecik Eğitim ve Araştırma Hastanesi Diyaliz Ünitesi, İzmir, Türkiye

Geliş Tarihi: 29 Mayıs 2020

Kabul Tarihi: 30 Mayıs 2020

\section{İletişim / Correspondence:}

Yaprak ORDİN

E-posta: yapraksarigol@gmail.com

\begin{abstract}
Özet
Koronavirus Hastalığı 2019 (COVID-19) salgını tüm Dünyayı etkisine almış ve herkesin hayatını etkilemiştir. Hemodiyaliz, periton diyalizi ve organ nakli hastaları, COVID-19'un şiddetli seyretmesi açısından risk grubundadır. Bu hasta grubunun dikkat etmesi gereken noktalar kendi hayatlarını korumaları açısından oldukça önemlidir. Ayrıca, her ülkenin mevcut sağlık sisteminde öz kaynaklarını ve salgını yöntebilmesi için riskli hasta gruplarına özel bilgilendirme yapması önemlidir. Dünya’nın birçok yerinde ve ülkemizde bu hasta grubunun izlem ve takibinin uzaktan yapılması ve hastaların bilgilendirilmesinin üzerinde durulmaktadır. Bu amaçla Türk Nefroloji, Diyaliz ve Transplantasyon Hemşireliği Derneği COVID-19 Komisyonu tarafından hastalarımızı bilgilendirmek için hasta rehberleri oluşturulmuştur. Nefroloji Hemşireliği Dergisinin bu sayısında meslektaşlarımıza yol göstermesi ve hastalarımızın bilgilendirilmese yardımcı olması amacıyla bu rehberler yer almaktadır.
\end{abstract}

Anahtar kelimeler: COVID-19, Hemodiyaliz, Periton Diyalizi, Organ Nakli, Hasta Rehberi 


\begin{abstract}
The Coronavirus Disease 2019 (COVID-19) outberak affected the whole World and affected everyone's life. Hemodialysis, peryton dialysis and organ transplant patients are in the risk group for severe course of COVID-19. The points that the patients group should pay attention to are very important in terms of protecting their own lives. In addition, it is important for each country to provide special information to risky patient groups in order to direct their own resources and epidemic in the current health system. In many parts of the World and in our country, it is emphasized to monitor and follow up this patients group remotely and inform patients. Therefore, patients guides were created by the Turkish Nephrology, Dialysis and Transplantation Nurses Association COVID-19 commission to inform our patients. In this issue of 'Journal of Nephrology Nursing', these guides are included to guide our colleagues and help inform our patients.
\end{abstract}

Key words: COVID-19, Hemodialysis, Periton Dialysis, Organ Transplantation, Patient Guide

\section{GİRIŞ}

Koronavirüs Aralık 2019 Çin'in Wuhan şehrinde birçok pnömoni vakasına sebep olması ile birlikte tanınmıștır. Bu virus akut solunum sendromu Koronavirüs 2 (SARS-CoV-2) olarak bilinmekte olup ilk olarak, koronovirüs hastalığı 2019Corona Virus Disease 2019 (COVID-19) olarak adlandırılmıştır. COVID-19 ilk olarak Çin'de görüldükten sonra tüm dünyaya yayılmıştır. Ülkemizde ilk vaka 11 Martta görülmüş olup aynı tarihte Dünya Sağlık Örgütü tarafından pandemi olarak duyurulmuştur. Tüm dünyayı saran bu salgında tüm sağllk sisteminin bu konuda stratejiler belirlemesi gerekmektedir. Ayrıca, bu süreçte enfeksiyonun kontrol altına alınması, bulaşın önlenmesi ve sağlık merkezlerinde takibi devam eden hastaların bilgilendirilmesi önemlidir. Tüm Dünya'yı saran ve daha önce eşi görülmemiş bu salgında, hemodiyaliz, periton ve organ nakli hastalarımız, COVID-19 Yeni Korona Virüs Hastalığının şiddetli seyretmesi açısından risk altındadır. Ayrıca bu hasta gruplarında COVID-19 hastalığı nedeniyle ölüm oranları genel popülasyona göre yüksektir. Her ülkenin kendi sağlık sistemi kaynaklarını yönetebilmesi açısından risk grubunda ki hastaların korunması oldukça önemlidir. COVID-19 oldukça yeni bir viral hastalık olup aşısı ve etkili bir tedavi yöntemi henüz mevcut değildir. $\mathrm{Bu}$ şartlarda salgının kontrol altına alınması, sağlık sisteminin korunması ve hastalarımızın hayatta kalması için yapılabilecek en önemli uygulama korunmadır. Sağlık profesyonelleri olarak elimizde ki en iyi silah hastalarımıza bu enfeksiyonun bulaşının önlenmesidir. Bunun içinde korunma yöntemleri konusunda hastalarımızın bilgilendirilmesi gereklidir. Sağlık sisteminde önemli bir yeri olan hemşirelerin temel görev ve sorumlulukları içerisinde hasta bilgilendirmesi ve eğitim yer almaktadır.

Bu kapsamda, Türk Nefroloji, Diyaliz ve Transplantasyon Hemşireleri Derneği COVID -19 Komisyonu tarafından hasta rehberleri oluşturulmuştur. Bu rehberler hazırlanırken, ağırlıklı olarak Dünya Sağlık Örgütü (DSÖ) önerileri, Hastalık Kontrol Merkezi (Centers for Disease Control and Prevention-CDC), ilgili meslek örgütlerinin bilgilendirme platformları, uluslararası klavuzlar ve Sağlık Bakanlığı Bilimsel Kurul Kararlarından yararlanılmış, güncel ve bilimsel gelişmeler ışığında da gözden geçirilmiștir. Tüm dünyayı etkisi altına alan ve çok ciddi can kaybina neden olan COVID-19 Yeni Koronavirüs Hastalığıyla mücadelede "Organ nakli olan hastalara yönelik COVID-19 Koronavirüs hastalığı rehberi”, "Periton diyalizi hastalarına yönelik COVID-19 Koronavirüs hastalığı rehberi", "Hemodiyaliz hastalarına yönelik COVID-19 Koronavirüs hastalığı rehberi” ve "Ev hemoiyalizi hastalarına yönelik COVID-19 hastalığı rehberi” hastalarımızın ve onlara bakım veren hasta yakınlarının, doğru bilgilendirilmesi ve gerekli korunma önlemlerini alması için hazırlanmıştır. $\mathrm{Bu}$ rehberlerde bu hastaların sağlıklı ve güvende kalmasına yardımcı olacak bilgiler ve kaynaklar, ayrıca "Sık Sorulan Sorular"a verilen yanıtlar yer almaktadır. 
PERITON DIYYALİZi, HEMODIYYALİ, EV DIYALIZİ VE ORGAN NAKLI OLAN, HASTALARA YÖNELİK COVID-19 KORONAVİRÜS HASTALIĞI REHBERİ

Bu rehber, tüm dünyayı etkisi altına alan ve çok ciddi can kaybına neden olan COVID-19 Yeni Koronavirüs Hastalığıyla mücadelede hali hazırda Periton Diyalizi, Hemodiyaliz, Ev diyalizi ve Organ Nakli Olmuş hastalarımızın ve onlara bakım veren hasta yakınlarının, doğru bilgilendirilmesi ve gerekli korunma önlemlerini alması için Türk Nefroloji, Diyaliz ve Transplantasyon Hemşireleri Derneği COVID-19 Komisyonu tarafından hazırlanmıştır. Rehber hazırlanırken, ağırlıklı olarak Dünya Sağlık Örgütünün (DSÖ) önerileri, uluslararası kılavuzlar ve Sağlık Bakanlığı Bilim Kurulu kararlarından yararlanılmış, güncel ve bilimsel gelişmeler ışığında gözden geçirilmiştir.

Eşi görülmemiş bir dönemle karşı karşıyayız. Siz Periton Diyalizi, Hemodiyaliz, Ev diyalizi ve Organ Nakli olmuş hastalarımızı dinlemek ve desteklemek için burada olduğumuzu lütfen unutmayın; yalnız değilsiniz!

Hazırlamış olduğumuz rehberde, sizin ve sevdiklerinizin sağlıklı ve güvende kalmasına yardımcı olacak bilgileri ve kaynakları, ayrıca "Sık Sorulan Sorular"a verilen yanıtlarımızı bulabilirsiniz.

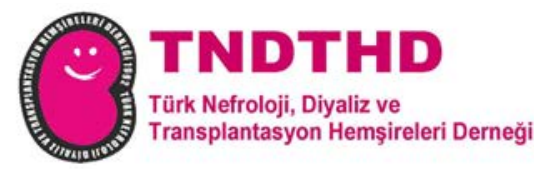

TÜRK NEFROLOJi, DIYALIZ VE TRANSPLANTASYON HEMŞiRELERI DERNEĞi

\section{HEMODIYALIZ HASTALARINA YÖNELIKK COVID-19 KORONAVİRÜS HASTALIĞI REHBERİ}

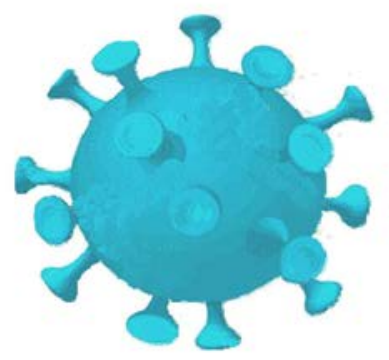

07.05.2020 


\section{COVID-19}

Komisyon Üyeleri

\section{Başkan \\ Ayten KARAKOÇ}

\section{Nermin ERDOĞAN}

THD COVID-19 Komisyon Üyesi ve Hemodiyaliz Rehberi Sorumlu Yazart

\section{Yaprak SARIGÖL ORDİN}

Organ Nakli Rehberi Sorumlu Yazan

\section{Güler NASUHBEYOĞLU}

Periton Diyaliz Rehberi Sorumlu Yazan

\section{Fatma ERSOY}

Ev Hemodiyalizi Rehberi Sorumlu Yazan

\section{Gülseren PEHLIVAN}

Sevel YILDIZ Sevginar ŞENTÜRK

\section{Tasarım}

ninetasarim@gmail.com 


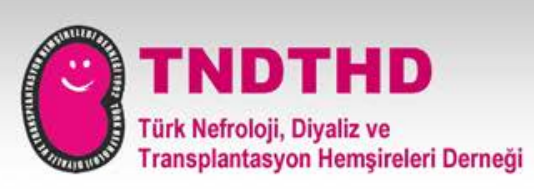

\section{HEMODIYALİZ HASTALARINA YÖNELIKK COVID-19 KORONAVIRÜS HASTALIĞI REHBERİ}

Bu rehber, tüm dünyayı etkisi altına alan ve çok ciddi can kaybına neden olan COVID-19 Yeni Koronavirüs Hastalığıyla mücadelede hali hazırda Hemodiyaliz tedavisinde bulunan hastalarımızın ve onlara bakım veren hasta yakınlarının, doğru bilgilendirilmesi ve gerekli korunma önlemlerini alması için Türk Nefroloji, Diyaliz ve Transplantasyon Hemşireleri Derneği COVID-19 Komisyonu tarafından hazırlanmıştır.

Rehber hazırlanırken, ağırlıklı olarak Dünya Sağlık Örgütününün (DSÖ) önerileri, uluslararası kılavuzlar ve Sağıı Bakanlığı Bilim Kurulu Kararlarından yararlanılmış, güncel ve bilimsel gelişmeler ışığında gözden geçirilmiştir.

Eşi görülmemiş bir dönemle karşı karşıyayız. Siz Hemodiyaliz hastalarımızı dinlemek ve desteklemek için burada olduğumuzu lütfen unutmayın; yalnız değilsiniz!

Hazırlamış olduğumuz rehberde, sizin ve sevdiklerinizin sağlıklı ve güvende kalmasına yardımcı olacak bilgileri ve kaynakları, ayrıca Sık Sorulan Sorulara verilen yanıtlarımızı bulabilirsiniz.

Saygılarımızla

Türk Nefroloji, Diyaliz ve Transplantasyon Hemşireleri Derneği

COVID-19 Komisyonu 


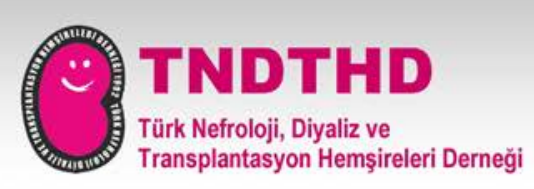

\section{HEMODIYALİZ HASTALARINA YÖNELİK}

\section{COVID-19 KORONAVIRÜS HASTALIĞI REHBERI}

\section{COVID-19 (Yeni Koronavirüs Hastalığı) Nedir?}

Yeni koronavirüs (COVID-19), ilk olarak Çin'in Wuhan şehrinde 2019 Aralık ayının son günlerinde solunum yolu belirtileri (ateş, öksürük, nefes darlığı) gelişen bir grup hastada yapılan araştırmalar sonucunda tanımlanan bir virüstür.

Daha sonra bu virüs Çin Halk Cumhuriyeti'nin diğer eyaletleri ve sonrasında da tüm dünyaya yayılmıştır. Dünya Sağlık Örgütü 12 Mart 2020 tarihinde COVID-19'a bağlı ortaya çıkan koronavirüs hastalığını pandemi (salgın) olarak ilan etmiştir.

\section{COVID-19'un (Yeni Koronavirüs Hastalığı) Belirtileri Nelerdir?}

COVID-19 koronavirüs hastalığının orta düzeyde ve şiddetli semptomları (belirtileri) vardır. Hastalık belirtileri virüse maruziyet (temas) sonrası 2-14 gün içinde görülmektedir.

Bu Belirtiler; Ateş, koku ve tat kayb1, öksürük, grip benzeri belirtiler (kas ağrısı, yorgunluk gibi) bulantı ve kusma, ishal ve karın ağrısı, solunum sıkıntısı, şiddetli olgularda; zatürre, ağır solunum yetmezliği ve ölüm gelişebilmektedir.

\section{COVID-19 (Yeni Koronavirüs Hastalığı) Nasıl Bulaşır?}

- Hasta bireylerin öksürmeleri, aksırmaları ile ortama saçılan damlacıkların solunması ile bulaşır.

- Hastaların solunum parçacıkları ile kirlenmiş yüzeylere dokunulduktan sonra ellerin yıkanmadan yüz, göz, burun veya ağıza götürülmesi ile de virüs alınabilir.

- Kirli ellerle göz, burun veya ağıza temas etmek risklidir. 


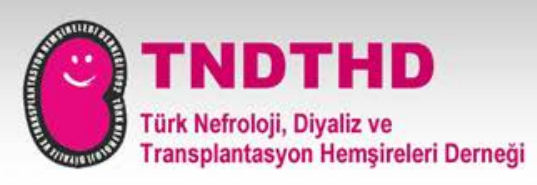

\section{Kimler COVID-19'un (Yeni Koronavirüs Hastalığı) Şiddetli} Seyretmesi Açısından Risk Grubundadır?

COVID-19 yeni bir hastalıktır ve bu hastalığın şiddetli seyretmesine neden olan risk faktörleri hakkında sınırlı bilgi vardır. Elimizde var olan bilgilere ve klinik deneyimlere göre;

\section{COVID-19 hastalığının şiddetli seyretmesi açısından yüksek riskli hastalar;}

- 65 yaş üstü insanlar

- Uzun süre huzurevinde kalan insanlar

- Ciddi sağlık sorunu olan herhangi bir yaş döneminde olan kişiler

- Astım ya da kronik akciğer hastalığı olanlar

- Ciddi kalp hastalığı olanlar

- Bağışıklık sistemi baskılanmış hastalar

- Kanser tedavisi gören hastalar

- Sigara içenler

- Kemik iliği ya da organ nakli olan hastalar

- İyi kontrol edilememiş AIDS hastaları

- Uzun süre kortizon ya da bağışıklık sistemini baskılayan ilaç kullanan hastalar

- Beden kitle indeksi 40 ve üstü olan kişiler (şişman hastalar)

- Diyabeti (şeker hastalığı) olan hastalar

- Kronik böbrek yetmezliği olan ve diyaliz tedavisi alan hastalar

- Karaciğer hastalığı olan hastalar

- Organ yetmezliği olan hastalardır.

Medyada görüntülenen ölüm ya da yoğun bakımdaki hastalar ile beraber akıldan çıkarılmaması gereken durum da \%80-85 oranında iyileşen hastalarımızın olduğudur. 


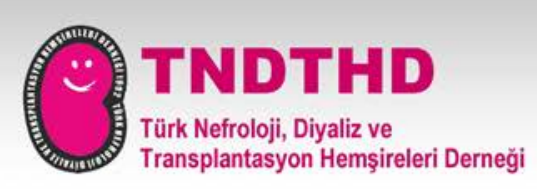

\section{COVID-19 Hastalığından Korunmak İçin Neler Yapılmalıdır?}

-Henüz COVID-19 Yeni koronavirüs hastalığı için koruyucu bir aş1 yoktur.

-En iyi korunma yöntemi virüse maruziyetten (temastan) kaçınmaktır.

- Bu virus insandan insana bulaşmaktadır.

- Covid 19 Yeni koronavirüs hastalığından kendinizi ve başkalarını nasıl koruyabileceğiniz konusunda Sağlık Bakanlığı, Halk Sağlığ1 Genel Müdürlüğü ve hekiminiz/hemşireniz tarafından verilen bilgileri dikkatlice takip edin ve uygulayın.

\section{KENDiNiZi KORUMANIN BELLİ BAŞLI ADIMLARI EVDE KALIN !!}

- Gerekli durumlar dışında dişarı çıkmayınız.

- Kalabalık yerlerde kesinlikle bulunmayınız.

- Toplu taşıma kullanmayınız.

- Birlikte yaşadığınız kişiler de mecbur olmadıkça dışarı çıkmamalıdır.

\section{ELLERINİZI SIK SIK YIKAYINIZ!!}

- Su ve sabunla en az 20 saniye (20'ye kadar sayarak) el yıkayınız. - Özellikle halka açık yerlerde bulunduktan sonra ellerinizi yıkayınız.

- Asansör, kapı kolu, wc vb. ortak kullanılan alanlara dokunduktan sonra ellerinizi su ve sabunla yeterli sürede ve sık sık yıkayınız.

- Siz ya da etrafınızdaki insanlar öksürdükten ya da aksırdıktan sonra ellerinizi yıkayınız.

-Su ve sabun yanınızda mevcut değilse, en az \%70 alkol içeren el antiseptiğiyle ellerinizi ovalayınız.

-Bu antiseptik ile ellerinizin tüm yüzeyini kaplayacak şekilde elleriniz kuruyana kadar ellerinizi ovalayınız.

-Yıkanmamış elleriniz ile ağız, burun ve gözlerinize dokunmayınız. 


\section{EL YIKAMA VE (ALKOL BAZLI) EL DEZENFEKTANLARI KULLANMA BROŞÜRÜ}

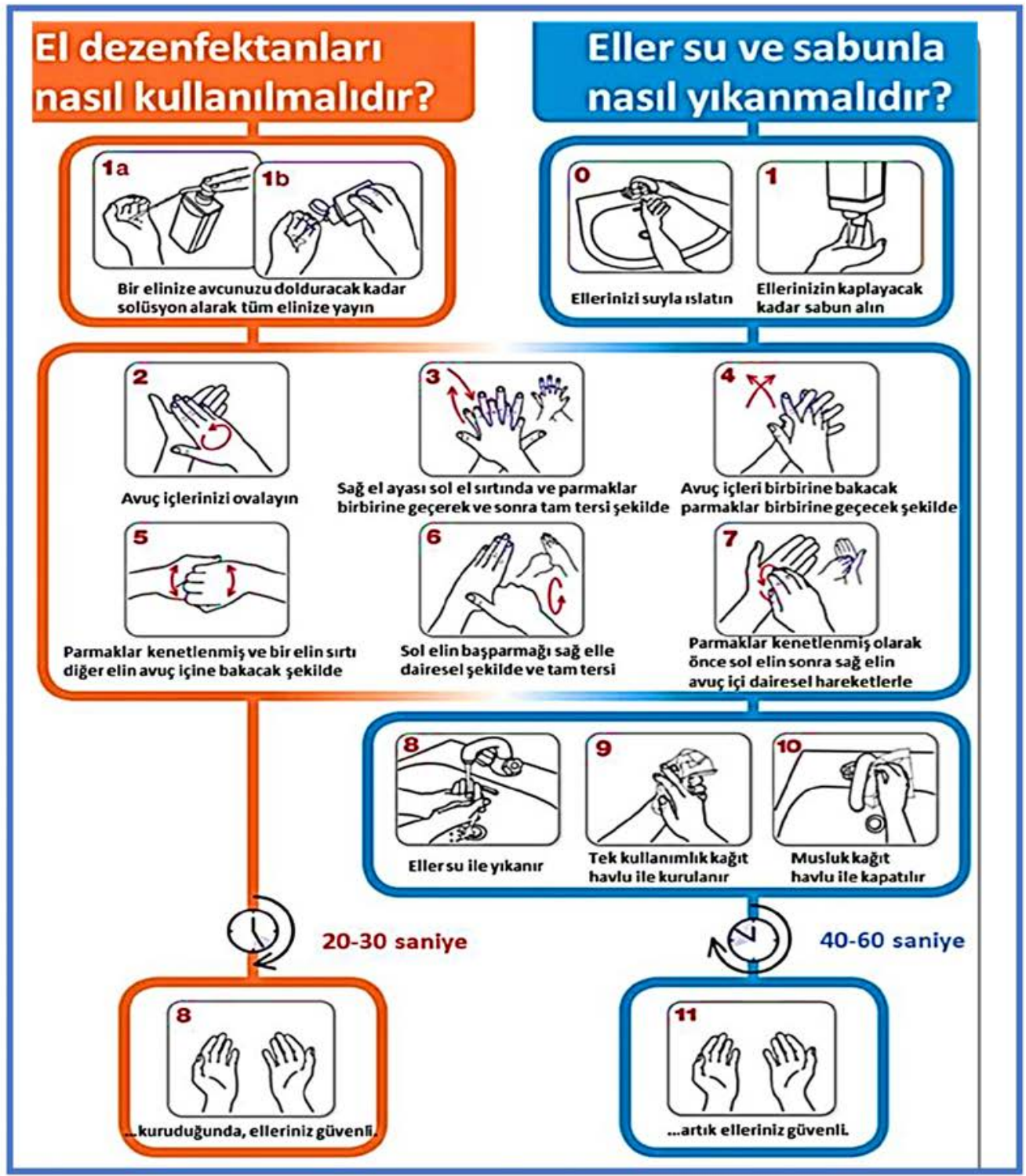

Kaynak 4. https://www.who.int/images/default-source/health-topics/coronavirus/riskcommunications / hand-cleaning/handrub.jpg?sfvrsn=e9b44b62_2 


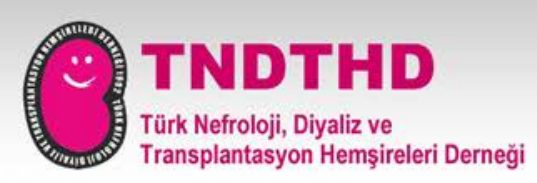

SOSYAL MESAFE NEDİR VE NASIL KORUNULUR

\section{Sosyal mesafe}

Bireyler arasındaki fiziksel teması en aza indirmeyi ve böylece enfeksiyon olasılığını azaltmak amacıyla kullanılır.

İnsanların buluştuğu yada toplandığı yerlerden uzak durmak, toplu taşıma araçlarından (örneğin otobüs, metro, minibüs, taksi birlikte binilen araba) kaçınmak ve diğer kişilerden uzaklı̆̆ korumak (3-4 adım) anlamına gelir.

Sosyal mesafeyi korumak için kişilerle (aile bireyleriniz dahil) aranıza her zaman 3-4 adım mesafe bırakınız ve dışarıda iseniz maskenizi takınız.

\section{Yakın Temastan Kaçınınız !!!}

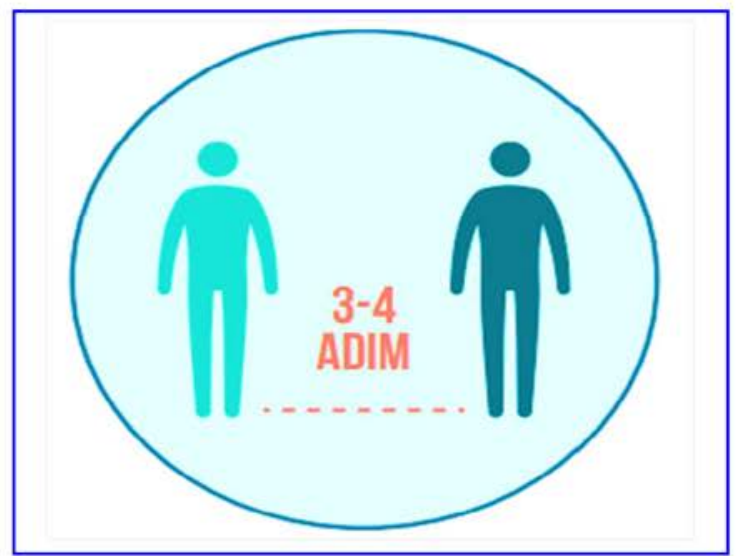

Kaynak 3: T.C. Sağlık Bakanlığı Halk Sağlığı Genel Müdürlüğü Yeni Koronavirüs Hastalığı (COVID19), Erişim: 11.04.2020 https://covid19bilgi.saglik.gov.tr/tr/

6: ECDC REPORT Guidance for social distancing measures aimed at minimising the spread of SARS-CoV-2 23 March 2020, Erissim tarihi: 07.04.2020 https://www.ecdc.europa.eu/sites/default/files/documents/covid-19-socialdistancing- 


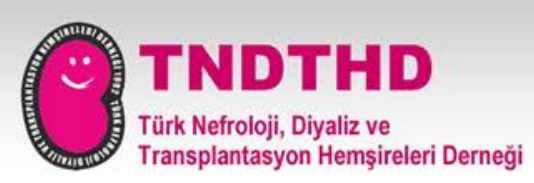

\section{Öksürme ve Hapşırma !!}

- Öksürme ve hapşırma sırasında burnunuzu ve ağzınızı tek kullanımlık kağıt mendil ile kapatınız.

- Kağıt mendiliniz yoksa dirsek içini bu amaçla kullanınız.

- Ellerinizi en kısa sürede su ve sabunla yıkayınız.

- Su ve sabun bulamıyorsanız, en az \%70 alkol içeren el antiseptiği ile ellerinizi ovalayınız.

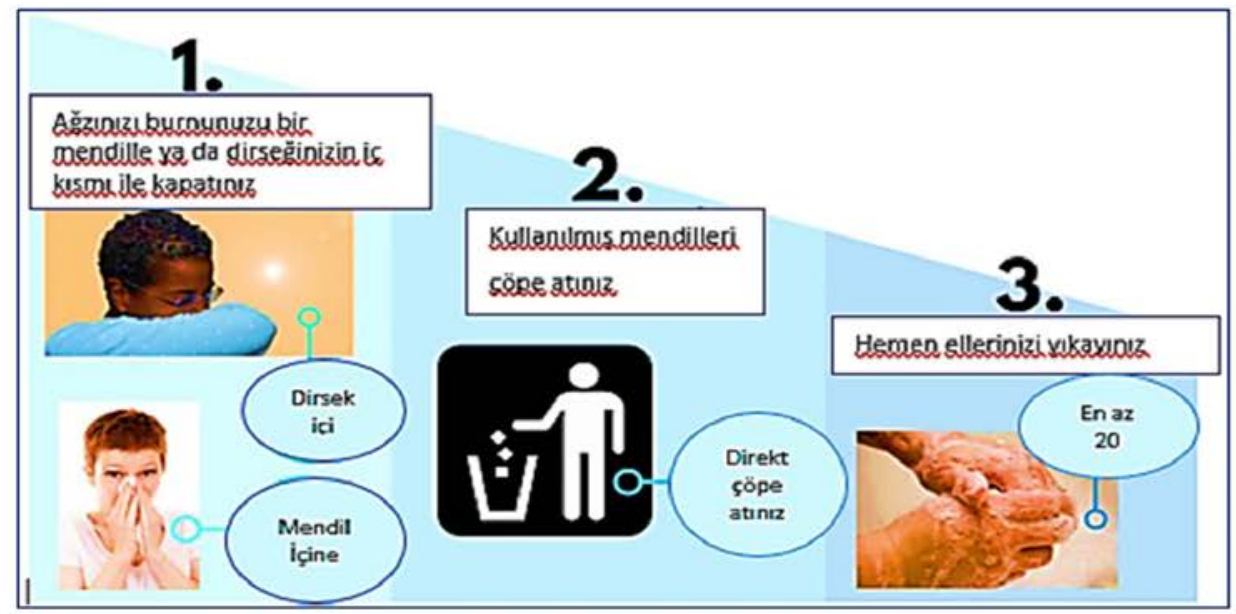

Şekil-1: 1.2 ve 3. Adımları öksürme ve hapşırmadan sonra uygulayınız.

Kaynak 7. AST.Power2Save one transplant for life. Coronavirus disease 2019 (COVID-19): FAQs for transplant candidates and recipients Erişimhttps://www.myast.org/coronavirus-disease-2019covid-19-frequently-asked-questions-transplant-candidates-and-recipients

\section{MASKE KULLANIMI !!}

- Tıbbi/Cerrahi maske olarak adlandırılan maskeleri kullanabilirsiniz.

- N95 olarak adlandırılan özellikli maskeleri sizler kullanmıyorsunuz.

- Evden dışarıya çıktığınızda mutlaka bu tıbbi/cerrahi maskeyi kullanınız.

- Sizinle birlikte kalan kişilerde dışarıya çıktıklarında maske kullanmalıdır. 


\section{TIBBİ/CERRAHİ MASKE KULLANIM BROŞÜRÜ}
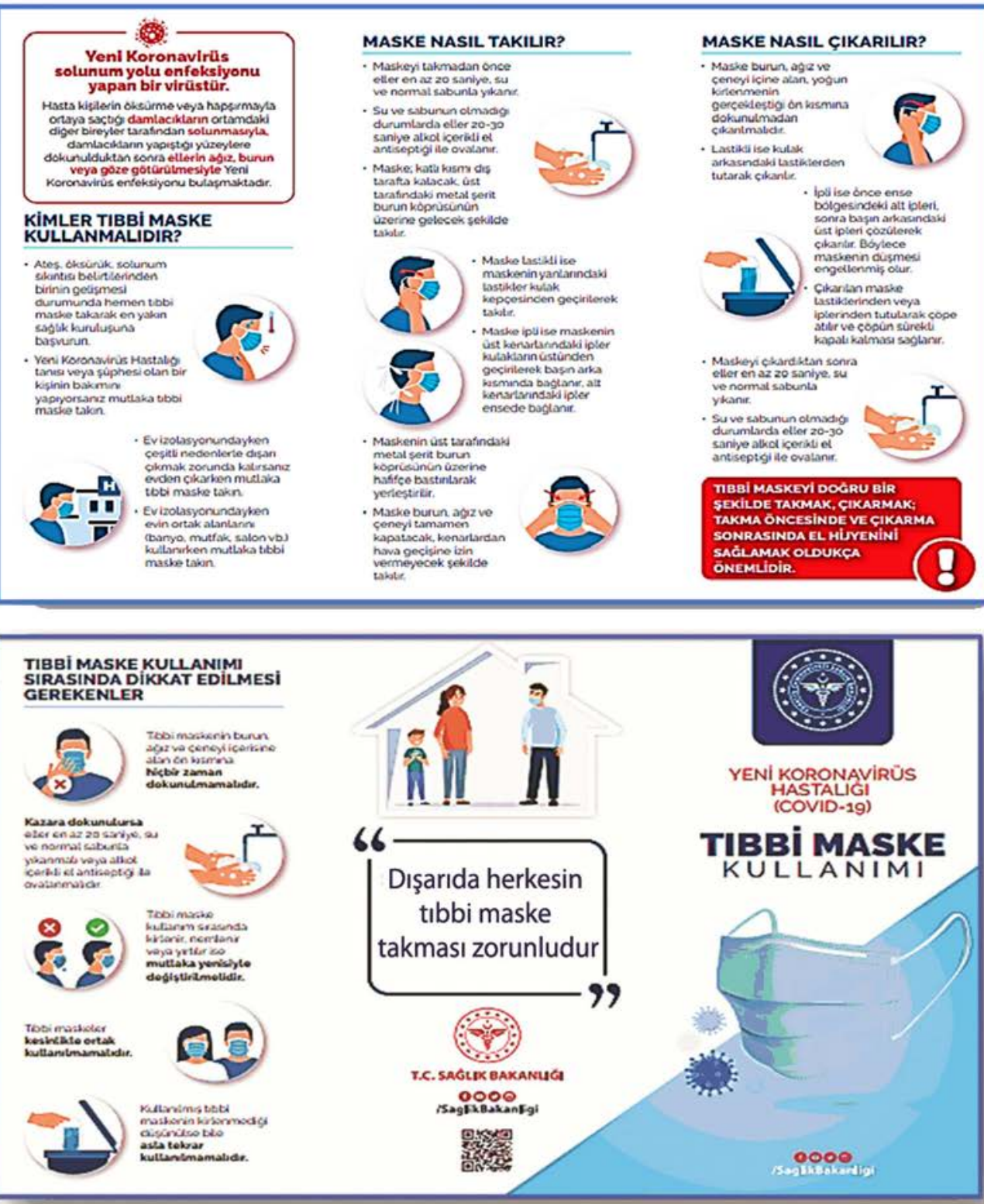


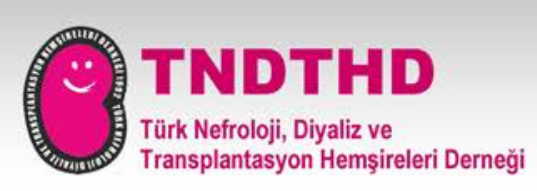

\section{TEMIZLIK VE DEZENFEKSIYON!!}

- Dokunduğunuz her yeri gün içinde sık sık deterjanla temizleyiniz.

- Gün içinde en fazla dokunulan yerler; Masa, sandalye, koltuk, kap1 kolları, 1şık prizi, anahtarlık, tezgahlar, telefonlar, tuvaletler, lavabolar, musluklar, kumandalar vb. yerleri s1k s1k temizleyiniz.

- Kirlenme olduysa kirlenen esya ya da yüzeyi hemen temizleyiniz.

-Yumuşak gözenekli yüzeyleri (hall, perde, koltuk vb.) görünür bir kirlenme varsa deterjanla temizleyiniz. Mutlaka kurumasını sağlayınız.

- Havlu, çamaşır, çarşaf gibi tekstil ürünlerinin temizliği sırasında silkelemekten kaçınınız, bu eşyaları çamaşır makinesinde mümkün olan en sicak 1sida (en az 60 derecede) y1kayınız ve kuruttuktan sonra ütüleyiniz.

- Dışarıda kullandığınız kıyafetleri eve girer girmez çıkarınız, dışarıdan içeriye ayakkabı sokmayınız. Dış giysi olarak kullan-at şeklinde şeffaf yağmurluk vb. giysiler kullanabilirsiniz.

- Hasta kişilerin, kirli giysilerini eldiven kullanarak tutunuz ve ayrı olarak (mümkünse bir file içinde) mümkün olan en sıcak isıda yıkayını.

- Eldiveninizi çıkardıktan sonra da ellerinizi en az 20 sn süre ile su ve sabunla yıkayınız.

\section{TEMİZLIK/DEZENFEKSIYYON İÇİN!!}

Günlük ev temizliğinde çamaşır suyu çözeltisi kullanabilirsiniz.

\section{Çamaşır suyu çözeltisi hazırlamak için:}

$\checkmark \quad 3$ litre suya 3 yemek kaşığı ya da bardağın 1/3'ü kadar çamaşır suyu

$\checkmark$ Ya da 1 litre suya 4 çay kaşı̆̆ı çamaşır suyu ekleyerek elde edebilirsiniz.

- Kullandiğınız çamaşır suyunun (üretici firmanın) uygulama ve uygun havalandırma talimatına uyunuz. 


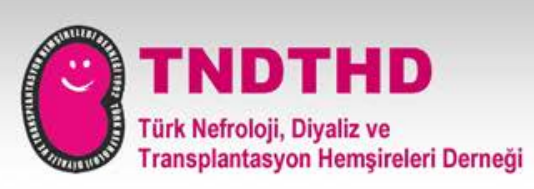

- Kullandığınız ürünün son kullanma tarihini kontrol ediniz.

- Ev tipi çamaşır suyunu asla amonyak ya da başka bir hiçbir temizleyici ile karıştırmayınız.

- Alkol solüsyonu kullanacak iseniz; En az \%70 alkol içeren solüsyon ile kullandığınız yüzeyleri dezenfekte ediniz.

\section{ETRAFINIZDA HASTA BİRI VARSA!!}

- Etrafınızda hasta biri varsa mümkünse aynı evde yaşamayınız.

- Evinizi ayırmanız mümkün değilse;

$\checkmark$ Bu kişiler ile tuvalet, banyo ve yatak odanızı, havlu, fırça gibi ortak kullanılan malzemeleri ayırınız.

$\checkmark$ Hasta olan kişinin, evde sizden ayrı olarak farklı bir odada kalmasını sağlayınız.

$\checkmark$ Yiyeceklerinizi ayırınız.

$\checkmark$ Bu kişilerin tabak, bardak, kaşık, çatal, bıçak gibi yemek yeme malzemelerini yıkarken bir eldiven kullanınız ya da bulaşı k makineniz var ise makinede yıkayınız.

$\checkmark$ Hasta olan kişinin çöplerini ayrı bir torbada toplayınız.

$\checkmark \mathrm{Bu}$ çöpler de atılırken eldiven kullanınız ve çöp torbasının ağzını sıkıca kapatınız. 


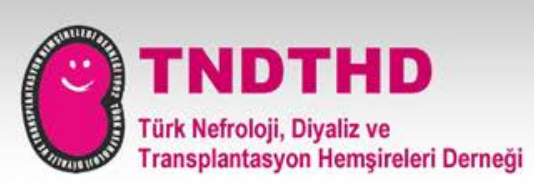

\section{HEMODIYYALİ HASTASI OLARAK DİKKAT ETMENİZ GEREKENLER}

1. Diyaliz tedavi gününüzde; Ateş ve solunum sıkıntısı olmadan sadece üst solunum yolları enfeksiyonuna ait belirtilerden (boğazda ağrı, boğazda yanma, halsizlik gibi) herhangi birisi var ise diyalize gelmeden önce mutlaka diyaliz merkezinize telefonla bilgi veriniz.

2. Üstte bahsedilen belirtilere ek olarak ateşiniz çıkarsa ve/veya öksürük, balgam ve nefes darlığı şikayetiniz olursa derhal tıbbi maske takınız ve Sağlık Bakanlığının Alo 184 Sabim Korona Danışma Hattını arayınız. Daha sonra Diyaliz merkezinize de durumunuz hakkında bilgi veriniz.

3. Evinizde Şüpheli/Pozitif Yeni Koronavirüs hastalığı nedeniyle karantina altında bir aile bireyiniz var ise mutlaka diyaliz merkezinizi bilgilendiriniz ve hasta olan bireyden kendinizi koruyunuz, maskenizi evde de takınız.

4. Diyaliz merkezine Ulaşım: Bu salgın döneminde diyaliz tedaviniz için evden merkeze kendi aracınızla gelip gitmeye çalışınız. (bu konuda aile bireylerinizden yardım isteyiniz)

5. Tıbbi maske kullanımı: Kendi sağlı̆̆ınız için evden çıkarken tıbbi maskenizi takınız ve tüm taşınma (evden merkeze, merkezden eve gidiş) süresince maskenizi asla çıkartmayınız.

6. Ellerin/fistül bölgesinin yıkanması: Diyaliz tedavinize gelmeden hemen önce ve merkeze geldiğinizde mutlaka ellerinizi ve fistüllünüzün bulunduğu bölgeyi su ve sabunla iyice yıkayınız. El yıkama olanağınız bulunmuyorsa Alkol bazlı el antiseptiği ile ellerinizi ovalayını. 


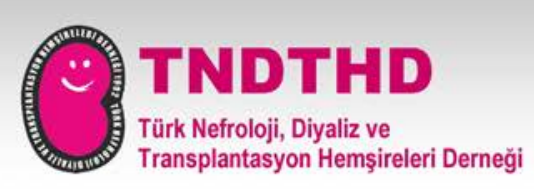

7. Bekleme Salonu Kuralları: Diyaliz merkezine geldiğinizde bekleme salonunda ki kalma sürenizi en aza indirmek için size söylenen tüm kurallara uyunuz, sosyal mesafenizi koruyunuz.

8. Diyaliz tedavi randevunuz: Bu salgın döneminde diyaliz tedaviniz için size bildirilen randevu günü, saati ve bazen tedavi salonunda, yatağınızda, makinenizde değişiklikler olabilir, diyaliz merkezinizin yöneticilerinden tedavi planlamanız konusunda herhangi bir değişiklik olup olmadığı hakkında bilgi alınız.

9.Ateş ve genel durum takibiniz: Diyaliz Merkezine gelir gelmez hemen, tedaviniz boyunca ve bitiminde ateş takibiniz sık olarak yapılacağı gibi, ateş, öksürük, nefes darlığı gibi belirtilerden herhangi birisinin olup olmadiğı yönünde de takip edileceksiniz, bu dönemde sağlığınızı yakından izlemek ve erkenden önlem almak adına yapılacak bu uygulamalarımız sizi ürkütmesin.

10. Diyaliz merkezlerinde yeme içme: $\mathrm{Bu}$ salgın döneminde diyaliz merkezlerinde yeme içme ile ilgili bir takım tedbirler alınmakta olup, tedavi esnasında yemek yemeniz sizin ve diğer hasta/sağlık çalışanlarının sağlığı açısından tehlike oluşturabilir. Lütfen diyaliz tedaviniz için evinizden merkeze gelmeden önce karnınızı doyurunuz. SSeker hastası iseniz, insulin miktarınızda ya da kullandığınız şeker ilaçlarınızda bir takım değişiklikler olabilir, doktorunuz ve hemşirenizden şeker tedavisi ilaçlarınız için bilgi alınız. Hipogliseminin önlenmesi için (kanda şekerin ani düşmesi durumu) yanınızda şeker bulundurunuz.

11. Refakat ve ziyaretçi kabulü: Diyaliz tedavinize gerekmediği sürece lütfen refakatçi getirmeyiniz. Diyaliz merkezlerinde tedavi edilen siz hastalarımızın yaşı, bizzat böbrek hastalığı ve eşlik eden hastalıklarınız (kalp hastalığı, şeker hastalığı ve akciğer hastalığı gibi) nedeniyle enfeksiyonlara karşı normal insanlara göre daha hassassınız. Bu çerçevede hasta refakati kabul 


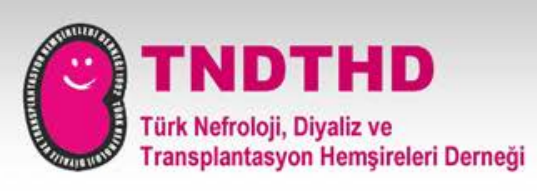

edilebilecek birkaç durum dişında olmayacaktır. (felçli ve yürüme problemi olan hastalar, ambulansla gelen hastalar, akli melekelerinde bozukluk olan hastalar gibi) Lütfen merkezinizin yöneticileri ile refakatçi kabul edilebilecek durumlar ve nasıl uygulandığı hakkında bilgi edininiz.

12. Diyaliz merkezinizin, yeni koronavirüs hastalığı ile ilgili ilave koruyucu ekipmanların kullanılması gibi pek çok düzenlemenin Sağlık Bakanlığı talimatıyla yapıldığını bilin, merkezinizin yöneticilerinden alınan önlemlerle ilgili bilgi edininiz.

13. İlaç temini: Sağlık Bakanlığının talimatıyla diyaliz tedavisinde, var ise ilave bir kronik hastalığınız ve bununla ilgili kullandığınız tüm ilaçların rapor süresi uzatılmıştır. Doktorunuzun size önerdiği ilaçları eczanenizden (siz/aile bireyleri) reçetesiz olarak alabilirsiniz. Bu süreçte düzenli olarak kullanmaya ve ilacınız bitmeden temin etmeye devam ediniz.

14. Beslenme şekliniz/diyetiniz: Diyaliz hekiminiz tarafından aksi bir şey belirtilmediği takdirde size önerilen besinleri tüketmeye devam ediniz. Bu dönemde çiğ sebze ve meyve tüketmekten kaçınınız. Yine bu dönemde yüksek potasyumlu, fosforlu ve tuzlu yiyeceklerden kaçınarak su tüketiminize (sıvı alımınızı) ve diyetinize uymak çok daha önemlidir. Çiğ et tüketmeyiniz, yiyeceklerinizi hazırlarken iyi yıkanmasına, iyi pişirilmesine ve taze olarak tüketilmesine her zamankinden daha fazla özen gösteriniz. Diyaliz hastası olarak yemekten önce, yemeklerle birlikte /sonra alacağınız ilaçlarınız var ise buna azami dikkat ediniz. 


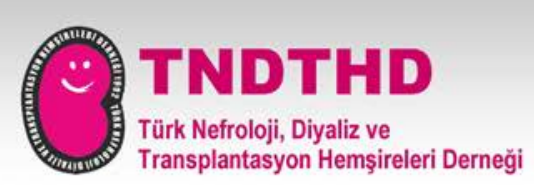

\section{SIK SORULAN SORULAR}

\section{Soru: Diyalize nasıl gideceğim? Sokağa çıkma yasağı ile ilgili tedbirler diyalize gitmeme engel olur mu?}

Cevap: Aksi bir durum belirtilmedikçe diyalize ulaşımınız programlandığı gibi devam edecektir. Merkezinizin yöneticilerinden Diyalize girdiğinize dair onaylı bir yazı ve diyaliz raporunuzun onaylı bir kopyasını isteyiniz, her zaman bu yazıyı yanınızda bulundurunuz. Sokağa çıkma yasağının uygulandığı tarihlerde kendi aracınızla merkeze gelmeniz durumunda bu yazıyı yetkililere göstermek üzere hazır bulundurunuz. Bunun dişında merkeziniz Hasta nakil araçlarıyla ulaşımınız halinde gerekli tüm yasal ve idari tedbirleri zaten alacaktır.

Soru: Yüksek tansiyonum var, tansiyon ilaçlarımı kesmeli veya değiştirmeli miyim?

Cevap: Tansiyon ilaçlarının bu hastalığın seyrini olumsuz etkilediğine dair bilgi kanıtlanmış değildir. Şu anda, belirli bir tansiyon ilaç grubunun bu hastalığı nasıl etkilediğine dair bir kanıt bulunmamaktadır. Başta tansiyon ilaçlarınız da dâhil olmak üzere tüm reçeteli ilaçlarınıza diyaliz hekiminizin size reçete ettiği şekilde devam etmeniz ve ilaçlarınızı hekiminizle görüşmeden kesinlikle kesmemeniz önemlidir.

Soru: Diyaliz hastası olarak seyahat etmemde bir sakınca var m1, kendi merkezimden başka bir diyaliz merkezine gidebilir miyim?

Cevap: Sağlık Bakanlığının talimatları gereği diyaliz hastalarının bu salgın hastalık dönemi boyunca kendi tedavi gördükleri merkez dışında bir merkezde tedavi görmelerine sınırlama getirilmiştir. Sizin, ailenizin ve tedavi gördügünüz sağlı merkezi çalışanlarının sağlığının korunması, Covid-19 hastalığının 


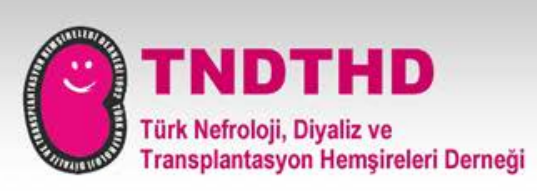

bulaşmaması adına bu sınırlama çok önemlidir. Şu an için şehirlerarası seyahatlere çok sıkı sınırlama getirilmiştir. Başka şehirlere yasağın kaldırılıp kaldırılmadığını İç İşleri Bakanlığının duyurularından takip edebilirsiniz.

Soru: Diyaliz hastası olarak Covid-19 hastalığının bana bulaşması ile ilgili çok ciddi kaygılarım var ve korkuyorum, korku ve kaygımı azaltmak için ne gibi önerileriniz olabilir?

Cevap: Bir kriz sırasında kendinizi üzgün, stresli, şaşkın, korkmuş veya kızgın hissetmeniz normaldir. Hepimizi tehdit eden bu belirsizlik durumuna eğer izin verirsek ruh sağlığımız da olumsuz etkilenecektir. Ruhsal sıkıntıların çarpıntı, terleme veya nefes alamama hissi gibi fiziksel şikâyetlere de neden olabileceği unutulmamalıdır ki bunlar beklenen, normal vücut reaksiyonlarıdır.

\section{Kendi sağlık durumunuz veya sevdiklerinizle ilgili korkularınız ve endişeleriniz:}

- Uyku ya da yemek düzeninde değişikliklere

- Uyumakta ya da konsantre olmakta zorluğa

- Kronik sağlık sorunlarının kötüleşmesine

- Alkol, sigara ya da diğer ilaçların kullanımının artmasına neden olabilmektedir.

\section{Bu gibi durumlarda güvendiğiniz insanlarla konuşmak size yardımcı olabilir.}

- Ailenizle ve arkadaşlarınızla iletişim kurunuz.

- Arkadaşlarınızla sadece telefonla iletişime devam ediniz.

- Endişelerinizle tek başınıza mücadele etmeye çalışmayınız.

- Başkalarıyla iletişim kurarak onlardan da destek alınız. 


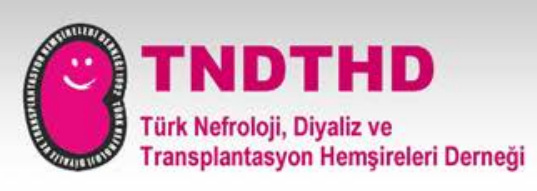

\section{SAĞLIKLI BİR YAŞAM İÇİN GENEL KURALLARA UYUN:}

1. İyi beslenin: Hastalığınız nedeniyle kısıtlanan yiyecekler haricinde dengeli besleniniz. Diyalizler arasinda fazla kilo almamaya özen gösteriniz. Vücutta aşırı sıvı birikiminin özellikle akciğerlerde enfeksiyon riski oluşturduğunu unutmayınız.

2. İyi uyuyun: Uyumadan önce zihninizi rahatlatmak için müzik dinleyin, kitap okuyun, sevdiklerinizi, geçmişteki güzel anılarınızı veya sizi mutlu edecek şeyleri düşününüz.

3. Egzersiz yapın: Kalabalık ortamlardan uzak durmak, soğuktan korunmak ve kendinizi aşırı yormamak koşuluyla yürüyüş gibi hafif egzersiz yapınız, Rahatlamak için kendinize zaman ayırınız, böylece bir süre sonra yoğun duygular geçecektir.

- Haberleri izlemeye, okumaya ya da dinlemeye mola veriniz.

- Tekrarlayan biçimde krizi duymak ve görüntüleri görmek üzücü olabilir.

- Normal yaşamınıza dönmek için hoşlandığınız diğer bazı etkinlikleri yapmaya çalışınız.

- Duygularınızla başa çıkmak için sigara, alkol veya diğer ilaçlardan uzak durunuz. Bunalmış hissediyorsanız hekiminizle paylaşın ve önerilerini alınız.

- Güvenilir kaynaklardan ve gerçek bilgiyi almaya çalışınız.

- Makul önlemler alabilmeniz için riskinizi doğru bir şekilde belirlemenize yardımcı olacak bilgileri dikkatlice takip ediniz.

- Gerçek dişı haberlerden uzak durunuz.

- Sizi ve ailenizi üzecek medya yayınlarını dinlemeyiniz ve izlemeyiniz. 


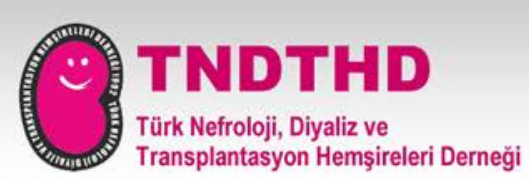

\section{Kaynaklar}

1. CDC-Centers of Disease Control and Prevention, Coronavirus Disease 2019 (COVID-19), Erişim: https://www.cdc.gov

2. ERA/EDTA COVID-19 guideline, Erişim: https://www.era-edta.org/en/ covid-19-news-and-information/

3. T.C. Sağlık Bakanlığı Halk Sağlı̆̆1 Genel Müdürlüğü Yeni Koronavirüs Hastalığı (COVID-19), Erișim: https://covid19bilgi.saglik.gov.tr/tr/

4. WHO-World Health Organization, www.who.int.Erişim:https://www.who. int/images/default-source/health-topics/coronavirus/risk-

communications/hand-cleaning/handrub.jpg?sfvrsn=e9b44b62_2

5. https://covid19bilgi.saglik.gov.tr/depo/afisler/COVID19-TIBBI-MASKEKULLANIMI-29X20-2KIRIMLI-BROSUR.pdf.pdf Erişim Tarihi: 07.04.2020

6. ECDC REPORT Guidance for social distancing measures aimed at minimising the spread of SARS-CoV-2 23 March 2020, Erișim tarihi: 07.04 .2020

https://www.ecdc.europa.eu/sites/default/files/documents/covid-19social-distancing-

7. AST.Power2Save one transplant for life. Coronavirus disease 2019 (COVID19): FAQs for transplant candidates and recipients Erisimhttps: //www.myast.org/coronavirus-disease-2019-covid-19-frequently-askedquestions-transplant-candidates-and-recipients

8. WHO: Coping with stress during the 2019-nCoV outbrake- https://www. who.int $/$ docs $/$ default-source/coronaviruse/ coping-with-stress.pdf?sfvrsn= 9845bc3a_2 https://www.cdc.gov/coronavirus/2019-ncov/daily-life-coping/ managing-stress-anxiety.html

9. Kidney Care UK: Managing anxiety and fear.https://www.kidneycareuk.org/ news-and-campaigns/coronavirus-advice/managing-anxiety-and-fear/

10. Türk Psikiyatri Derneği: Koronavirüs hastalığ 1 salgını sırasında ruh sağlığ stresle baş etme- 13 Mart 2020, https://www.psikiyatri.org.tr/ 2147 / koronavirus-hastaligi-salgini-sirasinda-ruh-sagligi-ve-stresle-bas-etme

11. Kidney Care UK: https://www.kidneycareuk.org/news-and-campaigns/ coronavirus-advice/\#dialysis

12. Davita Kidney Care: https://www.davita.com/covid-19-information 


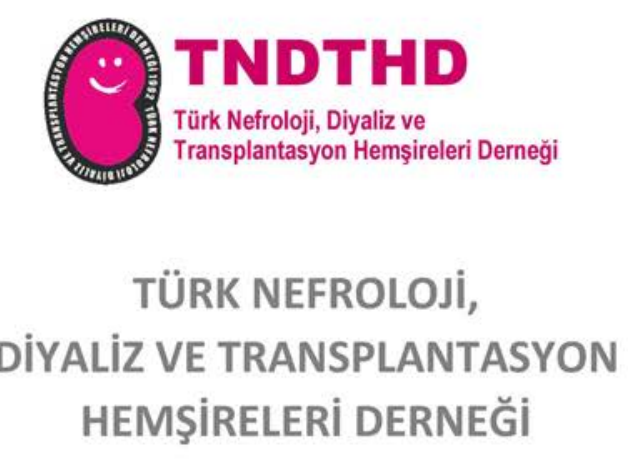

\section{PERÍTON DIYYALİİ HASTALARINA YÖNELİK COVID-19 KORONAVIRÜS HASTALIĞI REHBERİ}

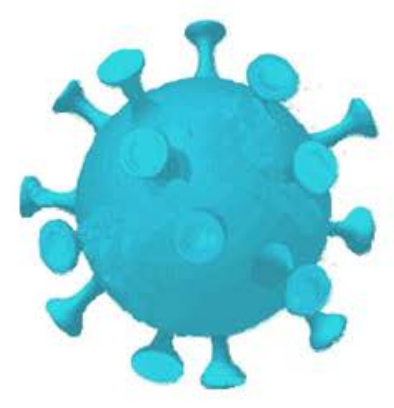

07.05 .2020 


\section{COVID-19}

Komisyon Üyeleri

\section{Başkan \\ Ayten KARAKOÇ}

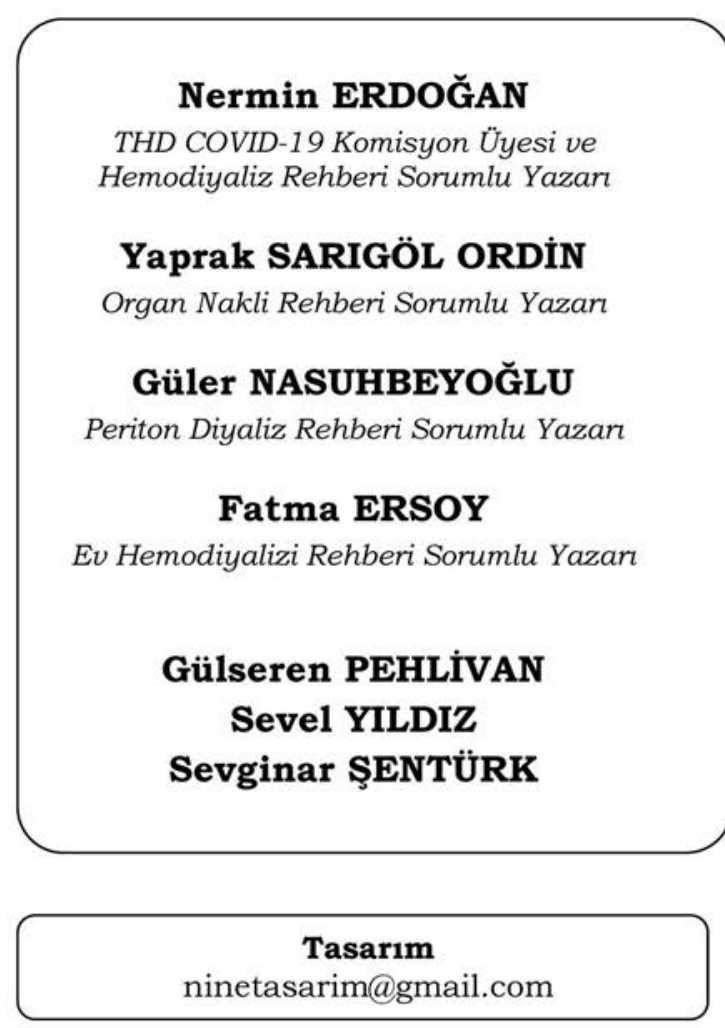




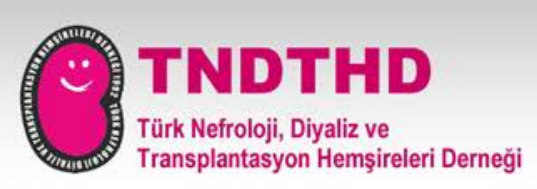

\section{PERITON DIYYALIZİ HASTALARINA YÖNELIKK COVID-19 KORONAVİRÜS HASTALIĞI REHBERİ}

Bu rehber, tüm dünyayı etkisi altına alan ve çok ciddi can kaybına neden olan COVID-19 Yeni Koronavirüs Hastalığıyla mücadelede Periton Diyalizi hastalarının ve onlara bakım veren hasta yakınlarının, doğru bilgilendirilmesi ve gerekli korunma önlemlerini alması için Türk Nefroloji, Diyaliz ve Transplantasyon Hemşireleri Derneği COVID-19 Komisyonu tarafından hazırlanmıştır.

Rehber hazırlanırken, ağırlıklı olarak Dünya Sağlık Örgütününün (DSÖ) önerileri, uluslararası kılavuzlar ve Sağıı Bakanlığı Bilim Kurulu Kararlarından yararlanılmış, güncel ve bilimsel gelişmeler ışığında gözden geçirilmiştir.

Eşi görülmemiş bir dönemle karşı karşıyayız. Siz Periton Diyalizi hastalarımızı dinlemek ve desteklemek için burada olduğumuzu lütfen unutmayın; yalnız değilsiniz!

Hazırlamış olduğumuz rehberde, sizin ve sevdiklerinizin sağlıklı ve güvende kalmasına yardımcı olacak bilgileri ve kaynakları, ayrıca Sık Sorulan Sorulara verilen yanıtlarımızı bulabilirsiniz.

Saygılarımızla

Türk Nefroloji, Diyaliz ve Transplantasyon Hemşireleri Derneği COVID-19 Komisyonu 


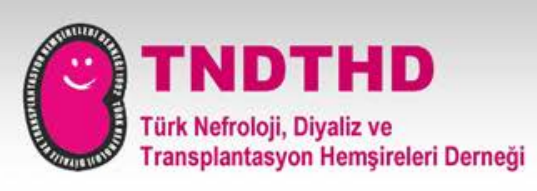

\section{PERITTON DIYYALİİ HASTALARINA YÖNELİK COVID-19 KORONAVİRÜS HASTALIĞI REHBERİ}

\section{CovID-19 (Yeni Koronavirüs Hastalığı) Nedir?}

Yeni koronavirüs (COVID-19), ilk olarak Çin'in Wuhan şehrinde 2019 Aralık ayının son günlerinde solunum yolu belirtileri (ateş, öksürük, nefes darlığı) gelişen bir grup hastada yapılan araştırmalar sonucunda tanımlanan bir virüstür.

Daha sonra bu virüs Çin Halk Cumhuriyeti'nin diğer eyaletleri ve sonrasında da tüm dünyaya yayılmıştır. Dünya Sağlık Örgütü 12 Mart 2020 tarihinde COVID-19'a bağlı ortaya çıan koronavirüs hastalığını pandemi (salgın) olarak ilan etmiştir.

\section{COVID-19'un (Yeni Koronavirüs Hastalığı) Belirtileri Nelerdir?}

COVID-19 koronavirüs hastalığının orta düzeyde ve şiddetli semptomları (belirtileri) vardır. Hastalık belirtileri virüse maruziyet (temas) sonrası 2-14 gün içinde görülmektedir.

Bu Belirtiler; Ateş, koku ve tat kayb1, öksürük, grip benzeri belirtiler (kas ağrısı, yorgunluk gibi) bulantı ve kusma, ishal ve karın ağrısı, solunum sıkıntısı, şiddetli olgularda; zatürre, ağır solunum yetmezliği ve ölüm gelişebilmektedir.

\section{COVID-19 (Yeni Koronavirüs Hastalığı) Nasıl Bulaşır?}

- Hasta bireylerin öksürmeleri, aksırmaları ile ortama saçılan damlacıkların solunması ile bulaşır.

- Hastaların solunum parçacıkları ile kirlenmiş yüzeylere dokunulduktan sonra ellerin yıkanmadan yüz, göz, burun veya ağıza götürülmesi ile de virüs alınabilir.

- Kirli ellerle göz, burun veya ağıza temas etmek risklidir. 


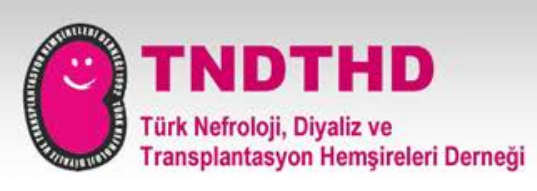

\section{Kimler COVID-19'un (Yeni Koronavirüs Hastalığı) Şiddetli Seyretmesi Açısından Risk Grubundadır?}

COVID-19 yeni bir hastalıktır ve bu hastalığın şiddetli seyretmesine neden olan risk faktörleri hakkında sınırlı bilgi vardır. Elimizde var olan bilgilere ve klinik deneyimlere göre;

\section{COVID-19 hastalığının şiddetli seyretmesi açısından yüksek riskli hastalar;}

- 65 yaş üstü insanlar

- Uzun süre huzurevinde kalan insanlar

- Ciddi sağlık sorunu olan herhangi bir yaş döneminde olan kişiler

- Astım ya da kronik akciğer hastalığı olanlar

- Ciddi kalp hastalığı olanlar

- Bağışıklık sistemi baskılanmış hastalar

- Kanser tedavisi gören hastalar

- Sigara içenler

- Kemik iliği ya da organ nakli olan hastalar

- İyi kontrol edilememiş AIDS hastaları

- Uzun süre kortizon ya da bağışıklık sistemini baskılayan ilaç kullanan hastalar

- Beden kitle indeksi 40 ve üstü olan kişiler (şişman hastalar)

- Diyabeti (şeker hastalığı) olan hastalar

- Kronik böbrek yetmezliği olan ve diyaliz tedavisi alan hastalar

- Karaciğer hastalığı olan hastalar

- Organ yetmezliği olan hastalardır.

Medyada görüntülenen ölüm ya da yoğun bakımdaki hastalar ile beraber akıldan çıkarılmaması gereken durum da \%80-85 oranında iyileşen hastalarımızın olduğudur. 


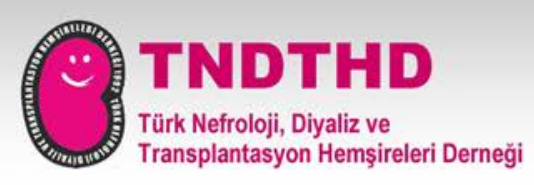

\section{COVID-19 Hastalığından Korunmak için Neler Yapılmalıdır?}

-Henüz COVID-19 Yeni koronavirüs hastalığı için koruyucu bir aşı yoktur.

-En iyi korunma yöntemi virüse maruziyetten (temastan) kaçınmaktır.

- Bu virus insandan insana bulaşmaktadır.

\section{KENDiNiZi KORUMANIN BELLİ BAŞLI ADIMLARI}

\section{EVDE KALIN !!}

- Gerekli durumlar dışında dışarı çıkmayınız.

- Kalabalık yerlerde kesinlikle bulunmayınız.

- Toplu taşıma kullanmayınız.

- Birlikte yaşadığınız kişiler de mecbur olmadıkça dışarı çıkmamalıdır.

\section{ELLERINİZI SIK SIK YIKAYINIZ !!}

- Su ve sabunla en az 20 saniye (20'ye kadar sayarak) el yıkayınız.

- Özellikle halka açık yerlerde bulunduktan sonra ellerinizi yıkayınız.

- Özellikle asansör, kapı kolu, wc vb. ortak kullanılan alanlara dokunduktan sonra ellerinizi su ve sabunla yeterli sürede ve sık sik yıkayınız.

- Siz ya da etrafınızdaki insanlar öksürdükten ya da aksırdıktan sonra ellerinizi yıkayınız.

- Eğer su ve sabun yanınızda mevcut değilse, en az \%70 alkol içeren el antiseptiğiyle ellerinizin tüm yüzeyini kaplayacak şekilde elleriniz kuruyana kadar ovalayınız.

- Yıkanmamış elleriniz ile ağız, burun ve gözlerinize dokunmayınız. 


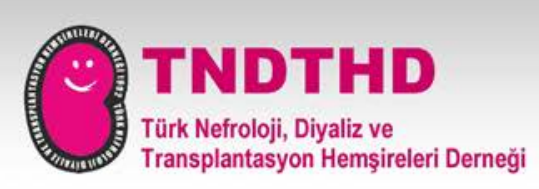

\section{EL YIKAMA VE (ALKOL BAZLI) EL DEZENFEKTANLARI KULLANMA BROŞÜRÜ}

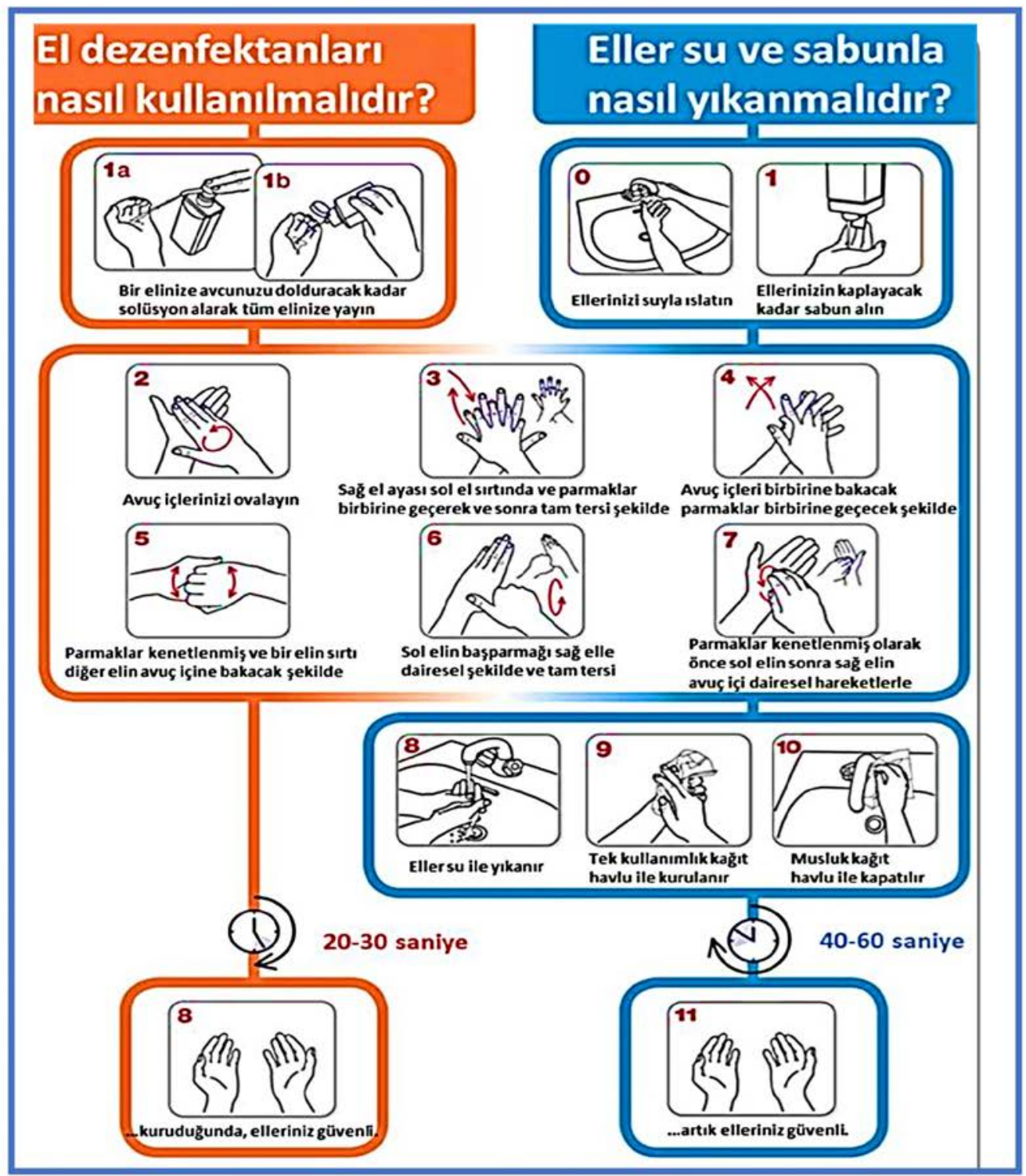

Kaynak 4. https://www.who.int/images/default-source/health-topics/coronavirus/riskcommunications/hand-cleaning/handrub.jpg?sfvrsn=e9b44b62_2 


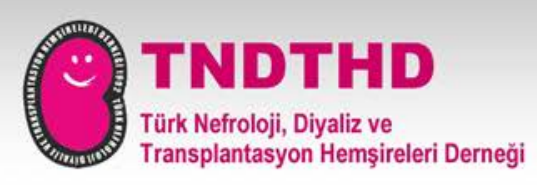

\section{SOSYAL MESAFE NEDIR VE NASIL KORUNULUR}

\section{Sosyal mesafe}

Çeşitli yollarla bireyler arasındaki fiziksel teması en aza indirmeyi ve böylece yeni enfeksiyon olasılığını azaltmak amacıyla kullanılır.

Sosyal mesafeyi korumak için kişilerle aranıza her zaman 3-4 adım mesafe bırakınız ve maskenizi takınız.

\section{Yakın Temastan Kaçınınız !!!}

- Etrafınızdaki insanlar ile aranızda mesafe bırakınız. (Sosyal mesafe)

- Özellikle sizin için diğer insanlar ile aranızda mesafe bırakmanız (3-4 adım) çok önemlidir.

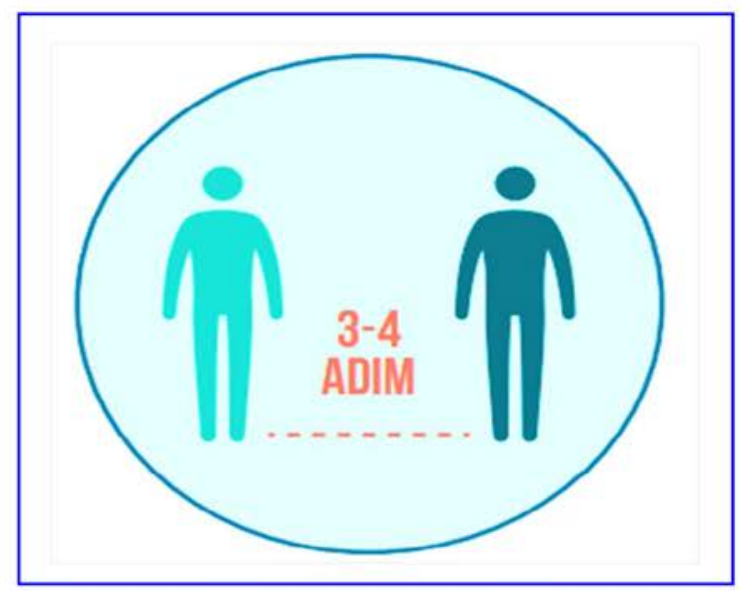

Kaynak 3: T.C. Sağlık Bakanlığı Halk Sağlığı Genel Müdürlüğg̈ Yeni Koronavirüs Hastalığı (COVID19), Erişim: 11.04.2020 https://covid19bilgi.saglik.gov.tr/tr/

6: ECDC REPORT Guidance for social distancing measures aimed at minimising the spread of SARS-CoV-2 23 March 2020, Erişim tarihi: 07.04.2020 https://www.ecdc.europa.eu/sites/default/files/documents/covid-19-socialdistancing- 


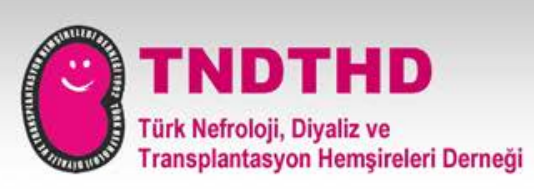

\section{Diğer İnsanları Korumak İçin !!}

- Hastaysanız, evde kalın ve sağlık merkezini arayınız.

- Cerrahi maskenizi mutlaka takınız.

- Diğer insanlar ile temasta bulunmayınız.

\section{Öksürme ve Hapşırma !!}

- Öksürme ve hapşırma durumunda hemen ellerinizi su ve sabunla yıkayınız.

- Eğer su ve sabun bulamiyorsanız, en az \%70 alkol içeren el antiseptiği ile ellerinizi ovalayınız.

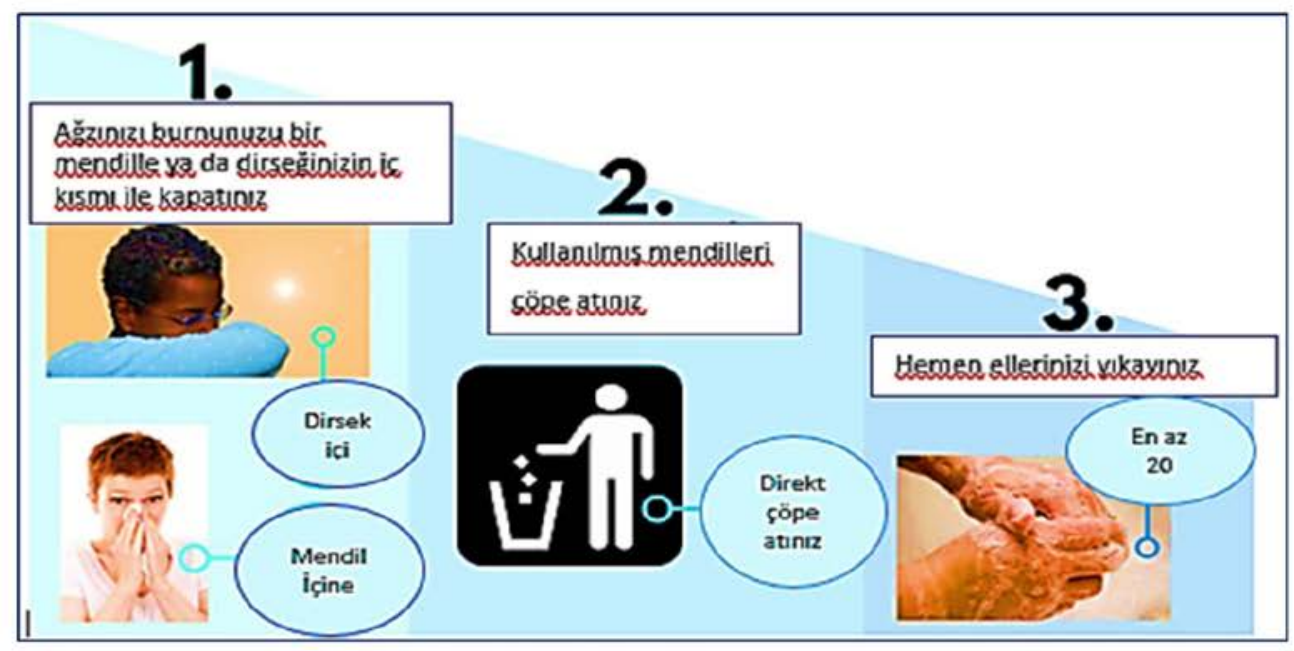

Şekil-1: 1.2 ve 3. Adımları öksürme ve hapşırmadan sonra uygulayınız.

Kaynak 7. AST.Power2Save one transplant for life. Coronavirus disease 2019 (COVID-19): FAQs for transplant candidates and recipients Erişimhttps://www.myast.org/coronavirus-disease-2019covid-19-frequently-asked-questions-transplant-candidates-and-recipients 


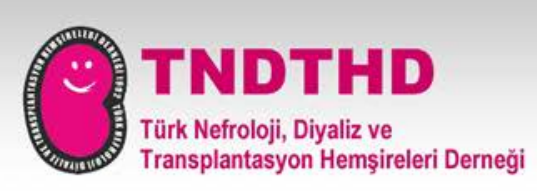

\section{TEMIZLIK VE DEZENFEKSIYON !!}

- Dokunduğunuz her yeri gün içinde sık sık deterjanla temizleyiniz.

- Gün içinde elle sık temas edilen; masa, sandalye, koltuk, kapı kolları, elektrik prizi, anahtarlık, tezgahlar, telefonlar, tuvaletler, lavabolar, musluklar, kumandalar vb. yerleri sık sık temizleyiniz.

- Kirlenme olduysa, kirlenen eşya ya da yüzeyi hemen temizleyiniz.

- Yumuşak gözenekli yüzeyleri (hall, perde, koltuk vb.) görünür bir kirlenme varsa deterjanla temizleyip mutlaka kurumasını sağlayınız.

- Havlu, çamaşır, çarşaf gibi tekstil ürünlerinin temizliği sırasında silkelemekten kaçınınız, bu eşyaları çamaşır makinesinde mümkün olan en sicak isıda (en az 60 derecede) yıkayınız ve kurutulduktan sonra ütüleyiniz.

- Dışarıda kullandığınız kıyafetleri eve girer girmez çıkarınız, dışarıdan içeriye ayakkabı sokmayınız. Dış giysi olarak kullan-at şeklinde şeffaf yağmurluk vb. giysiler kullanabilirsiniz.

- Hasta kişilerin, kirli giysilerini eldiven kullanarak tutunuz ve ayrı olarak (mümkünse bir file içinde) mümkün olan en sıcak 1sıda yıkayınız.

- Eldiveninizi çıkardıktan sonra da ellerinizi en az 20 sn süre ile su ve sabunla yıkayınız.

\section{TEMİZLIK/DEZENFEKSIYYON İÇİN!!}

Günlük ev temizliğinde çamaşır suyu çözeltisi kullanabilirsiniz.

\section{Çamaşır suyu çözeltisi hazırlamak için:}

$\checkmark \quad 3$ litre suya 3 yemek kaşığı ya da bardağın 1/3'ü kadar çamaşır suyu

$\checkmark$ Ya da 1 litre suya 4 çay kaşığı çamaşır suyu ekleyerek elde edebilirsiniz.

- Kullandığınız çamaşır suyunun (üretici firmanın) uygulama ve uygun havalandırma talimatına uyunuz. 


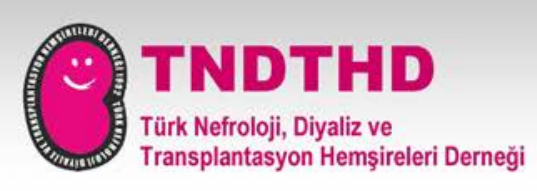

- Kullandığınız ürünün son kullanma tarihini kontrol ediniz.

- Ev tipi çamaşır suyunu asla amonyak ya da başka bir hiçbir temizleyici ile karıştırmayınız.

- Alkol solüsyonu kullanacak iseniz; En az \%70 alkol içeren solüsyon ile kullandığınız yüzeyleri dezenfekte ediniz.

\section{ETRAFINIZDA HASTA BİRİ VARSA !!}

- Etrafınızda hasta biri varsa mümkünse aynı evde yaşamayınız.

- Evinizi ayırmanız mümkün değilse;

$\checkmark$ Bu kişiler ile tuvalet, banyo ve yatak odanızı, havlu, fırça gibi ortak kullanılan malzemeleri ayırınız.

$\checkmark$ Hasta olan kişinin, evde sizden ayrı olarak farklı bir odada kalmasını sağlayınız.

$\checkmark$ Yiyeceklerinizi ayırınız.

$\checkmark$ Bu kişilerin tabak, bardak, kaşık, çatal, bıçak gibi yemek yeme malzemelerini yıkarken bir eldiven kullanınız ya da bulaşık makineniz var ise makinede yıkayınız.

$\checkmark$ Hasta olan kişinin çöplerini ayrı bir torbada toplayınız.

$\checkmark \mathrm{Bu}$ çöpler de atılırken eldiven kullanınız ve çöp torbasının ağzını sıkıca kapatınız.

\section{YAPMANIZ GEREKEN DIGĞER KORUYUCU ÖNLEMLER !!}

- Çiğ meyve ve sebze tüketmeyiniz, meyve ve sebzelerinizi yemeden önce çok iyi yıkayınız.

- Et ve et ürünlerini iyi pişiriniz, çiğ olarak tüketmeyiniz.

- Dişardan gelen tüm malzemeleri buzdolabına ve raflara koymadan önce mutlaka su ve sabunlu bezle siliniz, poşetlerini atınız ve buzdolabına bu poşetlerle koymayınız. 


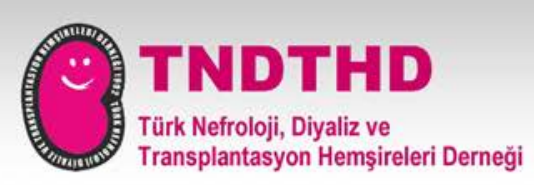

\section{MASKE TAKMA VE ÇIKARMA}

- Tibbi ya da cerrahi maske olarak adlandırılan maskeleri kullanabilirsiniz.

- N95 olarak adlandırılan özellikli maskeleri sizler kullanmiyorsunuz.

- Evden dışarıya çıktığınızda mutlaka tıbbi/cerrahi maske kullanınız.

- Sizinle birlikte kalan kişilere de dışarıya çıktıklarında maske kullandirınız.

- Maskeyi takmadan önce ve çıkarttıktan sonra mutlaka ellerinizi yıkayınız.

- Maskeyi burnunuzu, ağzınızı ve çenenizi tamamen içine alacak şekilde takınız.

- Maskenin telli kısmını burnunuzun üzerine gelecek şekilde takınız.

- Maskenizi nemlendikten sonra tekrar kullanmamalı, atmalı ya da yıkamalısiniz.

\section{Maske bulmada zorluk yaşamanız halinde;}

- E-devlet ile maske talebinde bulunabilirsiniz (PTT kargo, eNabiz).

- Kendinize evde az hava geçiren bezlerden maske yapabilirsiniz.

- Bu maskeleri günde bir kez 40 derece deterjanlı suda $30 \mathrm{dk}$ beklettikten sonra durulayıp kuruttuktan sonra ütüleyip kullanabilirsiniz.

- Bu maskeleri günde bir kez 60 derece sıcaklıkta çamaşır makinesinde yıkayıp, kuruttuktan sonra ütüleyip kullanabilirsiniz. 
TIBBİ/CERRAHI MASKE KULLANIMI

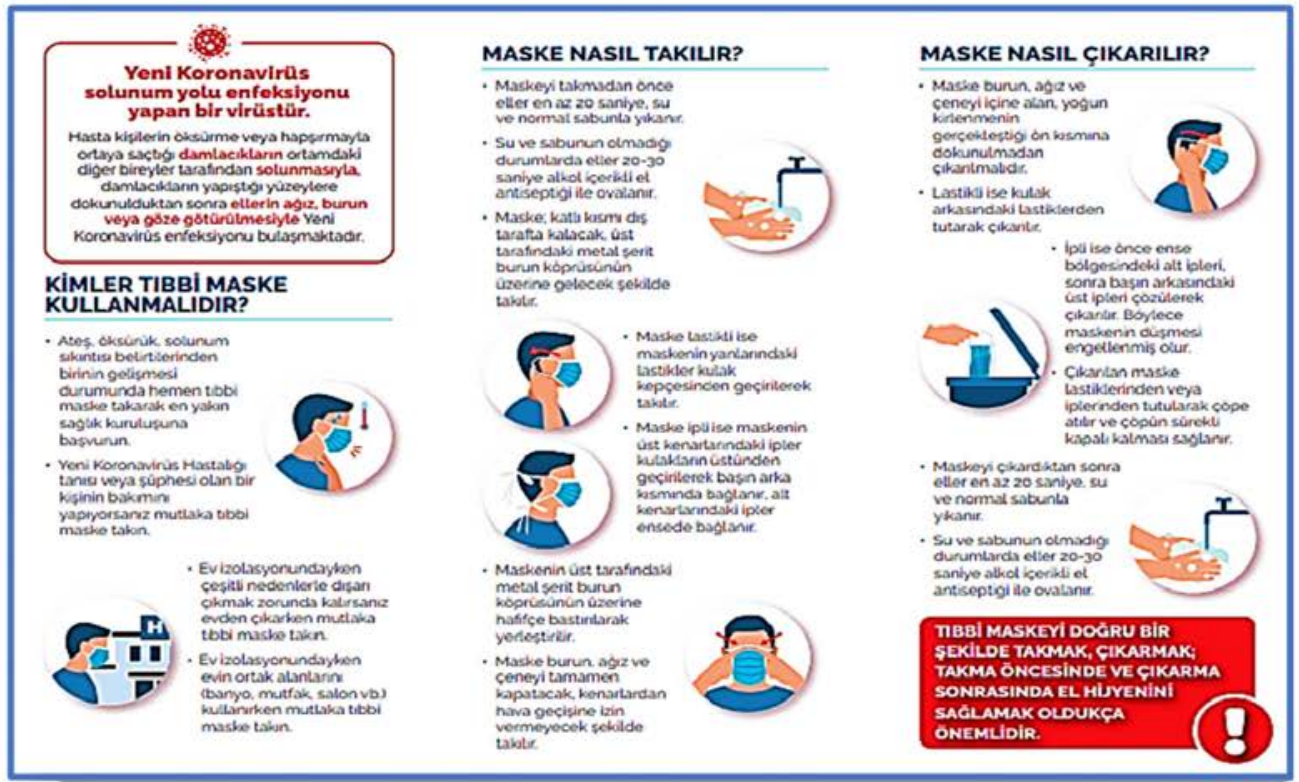

TIBBI MASKE KUULANIMI
SIRASINDA DIKKAT EDILMESI SIRASINDADI

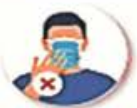

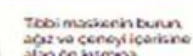

inich

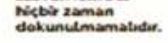

Kazara dokunulurs

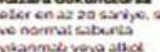

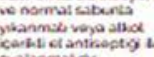

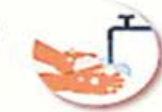

$\sum_{0}^{\infty}$

Tobimate

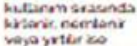

muttaka yeniciste

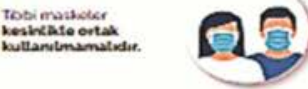

a)

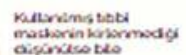

aiscinctis tes

kuttinimamatide.

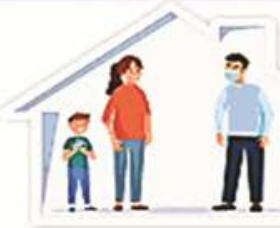

66

Dışarıda herkesin tıbbi maske takması zorunludur

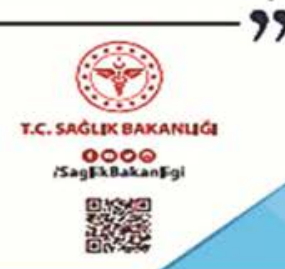

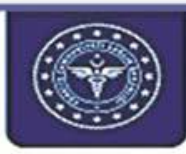

YENI KORONAVIRÜS HASTALIGI
(COVID-19)

TIBBI MASKE

KULLANIMI

0000 


\section{PERITTON DIYALIZI HASTASI OLARAK NELERE DİKKAT EDİLMELI??}

- Evinizi ve odanızı her gün en az $30 \mathrm{dk}$ havalandırınız.

- Hem kendinizde hem de ailenizden birinde Covid-19 yeni koronavirüs (pozitif) ve/veya şüpheli kişiler ile temas ihtimaline karşı evde kalmalı ve ziyaretçi kabul etmemelisiniz.

- Mümkünse diyaliz yaptığınız odaya kimsenin girmesine izin vermeyiniz.

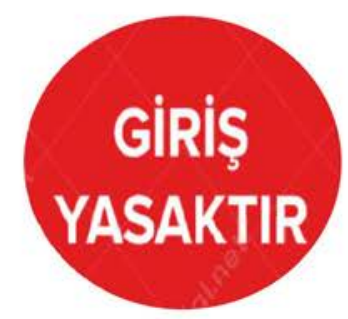

- Aletli periton diyaliz cihazlarınızın temizliğini daha dikkatli yapınız.

- Malzeme ve ilaç temininde sorunlar yaşanabilir bu nedenle en az iki haftalık ilaç, sıvı ve malzemenizi depolamanızı öneririz. Eczanenizden reçete numarası olmadan bir aylık ilaç ve malzeme temin edebilirsiniz.

- Size yeni gelen set ve malzemeleri mümkünse üç gün kullanmayınız, hemen kullanmak zorunda iseniz dezenfektan sıvı ile dış kılıfını siliniz.

- El Temizliğinize her zamankinden daha fazla özen gösteriniz!!!

*El temizliğinizi daha önce periton diyaliz ünitenizde almış olduğunuz eğitime uygun teknikle ve önerilen sürelerde yıkayınız. 


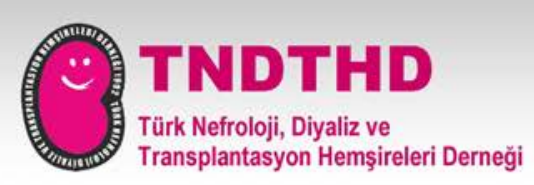

- Diyalize başlarken, sıvıları/setleri açtıktan sonra, bağlantı yapmadan önce, diyaliz bittikten sonra, diyaliz sıvılarınızı attıktan sonra mutlaka ellerinizi yıkayınız.

Alkol bazlı el temizleyicileri/el dezenfektanlarını ne zaman kullanmalısınız?

- Su ve sabun bulamadığınız zaman,

- Bağlantı yapmadan hemen önce,

- Bağlantıyı ayırıp yeni tek kullanımlık kapağı takmadan hemen önce kullanabilirsiniz.

\section{Acil durumlar dışında hastaneye gitmeyiniz (peritonit gibi).}

İstenmeyen ve baş edemediğiniz durumlarda telefon ile periton diyalizi hemşirenizi arayınız.
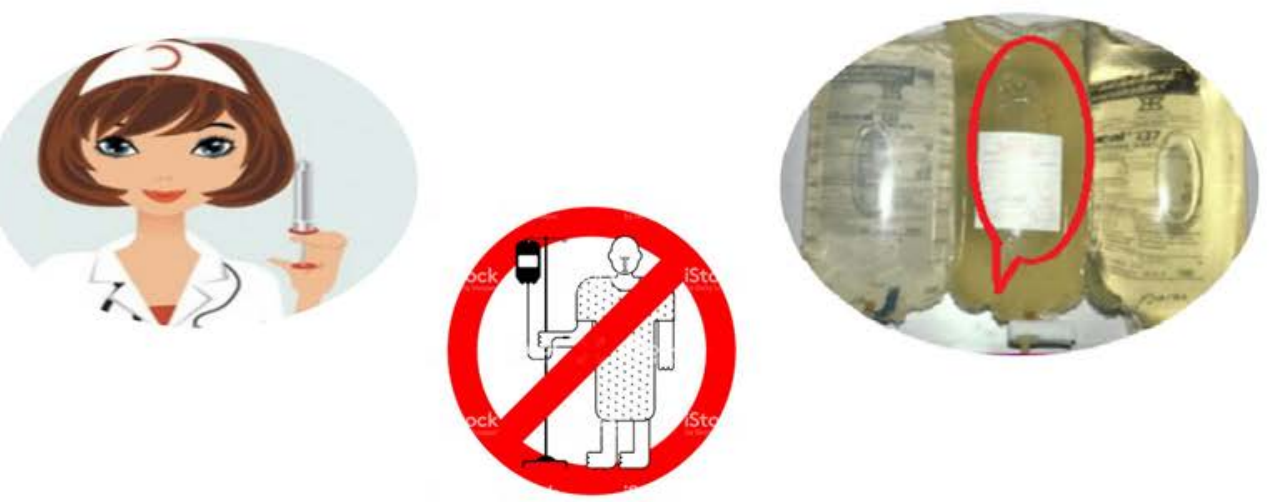

Sivı yüklenmesi belirtileri,

$>$ Kateter çıkış yeri problemleri,

> Boşaltım problemleri,

$>$ Baş edemediğiniz tedavi ile ilgili istenmeyen durumlar,

Covid-19 tanısı alırsanız hemşirenize mutlaka bilgi veriniz. !!! 


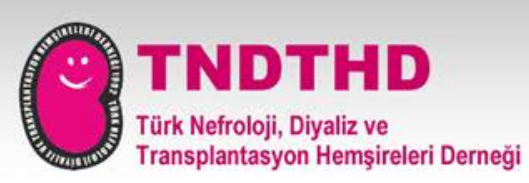

- Diyaliz sıvılarınızın tuvalete boşaltılması sırasında mutlaka maske ve eldiven kullanınız.

- Diyaliz sıvılarını tuvalete boşaltırken etrafa sıçramamasına dikkat ediniz, ardından çamaşır suyu dökünüz.

- Eldivenlerinizi çıkarttıktan sonra ellerinizi yıkayın ve sonrasında maskenizi çıkartınız.

- Diyaliz torba atıklarınızı ünitenizin önerdiği tıbbi atık önerilerine uygun atınız.

- COVID-19 yeni koronavirüs enfeksiyonu şüphesi varsa, çift torbaya koyunuz ve güvenli bir yerde saklayınız. 


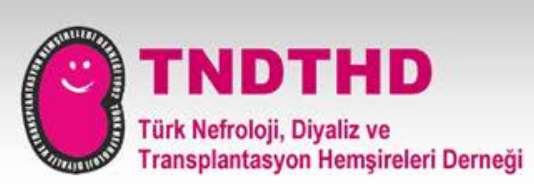

\section{Kaynaklar}

1. CDC-Centers of Disease Control and Prevention, Coronavirus Disease 2019 (COVID-19), Erişim: https://www.cdc.gov

2. T.C. Sağlık Bakanlığı Halk Sağlığı Genel Müdürlüğü Yeni Koronavirüs Hastalığ1 (COVID-19), Erişim: https:/ / covid19bilgi.saglik.gov.tr/tr/

3. WHO-World Health Organization, www.who.int.Erişim: https://www.who.int/ images/default-source/health-topics/coronavirus/risk-communications/handcleaning/handrub.jpg?sfvrsn=e9b44b62_2

4. https://covid19bilgi.saglik.gov.tr/depo/afisler/COVID19-TIBBI-MASKEKULLANIMI-29X20-2KIRIMLI-BROSUR.pdf.pdf Erişim Tarihi: 07.04.2020

5. AST.Power2Save one transplant for life. Coronavirus disease 2019 (COVID19): FAQs for transplant candidates and recipients Erişim https: //www.myast.org/coronavirus-disease-2019-covid-19-frequently-askedquestions-transplant-candidates-and-recipients

6. ECDC REPORT Guidance for social distancing measures aimed at minimising the spread of SARS-CoV-2 23 March 2020, Erişim tarihi: 07.04.2020 https://www.ecdc.europa.eu/sites/default/files/documents/covid19-social-distancing-

7. https://ispd.org/strategies-covid19/ ISPD: Strategies regarding COVID-19 in PD patients Erişim Tarihi:07.04.2020 


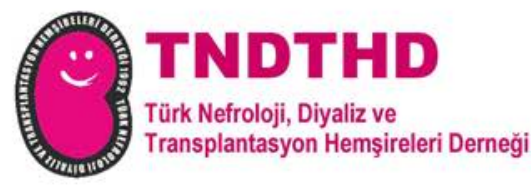

TÜRK NEFROLOJi, DIYALIZ VE TRANSPLANTASYON

HEMŞiRELERI DERNEĞi

\section{EV DİYALİZi HASTALARINA YÖNELİK COVID-19 (YENİ KORONAVIRÜS) HASTALIĞI REHBERİ}

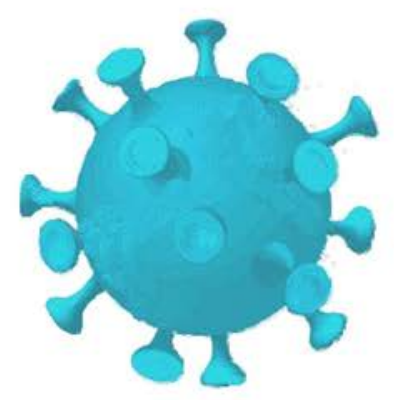

07.05 .2020 


\section{COVID-19}

Komisyon Üyeleri

\section{Başkan \\ Ayten KARAKOÇ}

\section{Nermin ERDOĞAN}

THD COVID-19 Komisyon Üyesi ve Hemodiyaliz Rehberi Sorumlu Yazart

Yaprak SARIGÖL ORDİN

Organ Nakli Rehberi Sorumlu Yazan

\section{Güler NASUHBEYOĞLU}

Periton Diyaliz Rehberi Sorumlu Yazan

\section{Fatma ERSOY}

Ev Diyalizi Rehberi Sorumlu Yazarı

\section{Gülseren PEHLIVAN}

Sevel YILDIZ Sevginar ŞENTÜRK

\section{Tasarım}

ninetasarim@gmail.com 


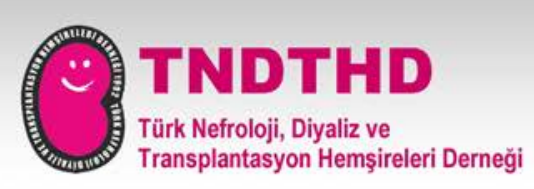

\section{EV DİYALİZI HASTALARINA YÖNELİK COVID-19 (YENI KORONAVIRÜS) HASTALIĞI REHBERI}

Bu rehber, tüm dünyayı etkisi altına alan ve çok ciddi can kaybına neden olan COVID-19 Yeni Koronavirüs Hastalığıyla mücadelede hali hazırda Ev Diyalizi hastalarımızın ve onlara bakım veren hasta yakınlarının, doğru bilgilendirilmesi ve gerekli korunma önlemlerini alması için Türk Nefroloji, Diyaliz ve Transplantasyon Hemşireleri Derneği COVID-19 Komisyonu tarafından hazırlanmıştır.

Rehber hazırlanırken, ağırlıklı olarak Dünya Sağlık Örgütününün (DSÖ) önerileri, uluslararası kılavuzlar ve Sağık Bakanlığı Bilim Kurulu Kararlarından yararlanılmış, güncel ve bilimsel gelişmeler ışığında gözden geçirilmiştir.

Eşi görülmemiş bir dönemle karşı karşıyayız. Siz Ev Diyalizinde ki hastalarımızı dinlemek ve desteklemek için burada olduğumuzu lütfen unutmayın; yalnız değilsiniz!

Hazırlamış olduğumuz rehberde, sizin ve sevdiklerinizin sağlıklı ve güvende kalmasına yardımcı olacak bilgileri ve kaynakları, ayrıca Sık Sorulan Sorulara verilen yanıtlarımızı bulabilirsiniz.

Saygılarımızla

Türk Nefroloji, Diyaliz ve Transplantasyon Hemşireleri Derneği

COVID-19 Komisyonu 


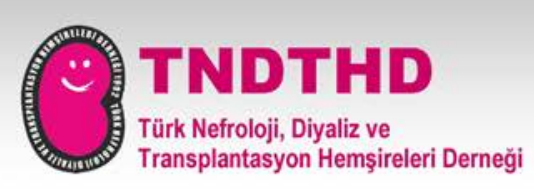

\section{EV DIYYALİZI HASTALARINA YÖNELİK COVID-19 (YENİ KORONAVIRÜS) HASTALIĞI REHBERİ}

\section{COVID-19 (Yeni Koronavirüs Hastalığı) Nedir?}

Yeni koronavirüs (COVID-19), ilk olarak Çin'in Wuhan şehrinde 2019 Aralık ayının son günlerinde solunum yolu belirtileri (ateş, öksürük, nefes darlığı) gelişen bir grup hastada yapılan araştırmalar sonucunda tanımlanan bir virüstür.

Daha sonra bu virüs Çin Halk Cumhuriyeti'nin diğer eyaletleri ve sonrasında da tüm dünyaya yayılmıştır. Dünya Sağlık Örgütü 12 Mart 2020 tarihinde COVID-19'a bağlı ortaya çıkan koronavirüs hastalığını pandemi (salgın) olarak ilan etmiştir.

\section{COVID-19'un (Yeni Koronavirüs Hastalığı) Belirtileri Nelerdir?}

COVID-19 koronavirüs hastalığının orta düzeyde ve şiddetli semptomları (belirtileri) vardır. Hastalık belirtileri virüse maruziyet (temas) sonrası 2-14 gün içinde görülmektedir.

Bu Belirtiler; Ateş, koku ve tat kayb1, öksürük, grip benzeri belirtiler (kas ağrısı, yorgunluk gibi) bulantı ve kusma, ishal ve karın ağrısı, solunum sıkıntısı, şiddetli olgularda; zatürre, ağır solunum yetmezliği ve ölüm gelişebilmektedir.

\section{COVID-19 (Yeni Koronavirüs Hastalığı) Nasıl Bulaşır?}

- Hasta bireylerin öksürmeleri, aksırmaları ile ortama saçılan damlacıkların solunması ile bulaşır.

- Hastaların solunum parçacıkları ile kirlenmiş yüzeylere dokunulduktan sonra ellerin yıkanmadan yüz, göz, burun veya ağıza götürülmesi ile de virüs alınabilir.

- Kirli ellerle göz, burun veya ağıza temas etmek risklidir. 


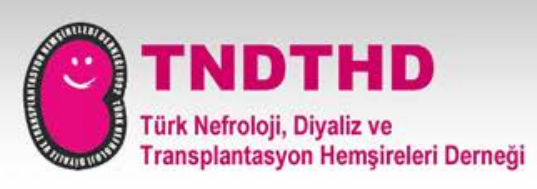

\section{Kimler COVID-19'un (Yeni Koronavirüs Hastalığı) Şiddetli} Seyretmesi Açısından Risk Grubundadır?

COVID-19 yeni bir hastalıktır ve bu hastalığın şiddetli seyretmesine neden olan risk faktörleri hakkında sınırlı bilgi vardır. Elimizde var olan bilgilere ve klinik deneyimlere göre;

\section{COVID-19 hastalığının şiddetli seyretmesi açısından yüksek riskli hastalar;}

- 65 yaş üstü insanlar

- Uzun süre huzurevinde kalan insanlar

- Ciddi sağlık sorunu olan herhangi bir yaş döneminde olan kişiler

- Astım ya da kronik akciğer hastalığı olanlar

- Ciddi kalp hastalığı olanlar

- Bağışıklık sistemi baskılanmış hastalar

- Kanser tedavisi gören hastalar

- Sigara içenler

- Kemik iliği ya da organ nakli olan hastalar

- İyi kontrol edilememiş AIDS hastaları

- Uzun süre kortizon ya da bağışıklık sistemini baskılayan ilaç kullanan hastalar

- Beden kitle indeksi 40 ve üstü olan kişiler (şişman hastalar)

- Diyabeti (şeker hastalı̆̆ı) olan hastalar

- Kronik böbrek yetmezliği olan ve diyaliz tedavisi alan hastalar

- Karaciğer hastalığı olan hastalar

- Organ yetmezliği olan hastalar. 


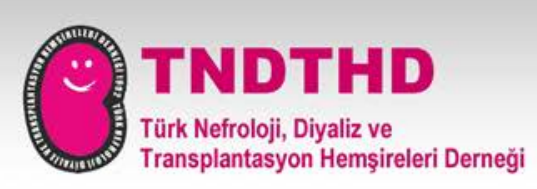

\section{COVID-19 Hastalığından Korunmak İçin Neler Yapılmalıdır?}

- Henüz COVID-19 Yeni koronavirüs hastalığı için koruyucu bir aşı yoktur.

- En iyi korunma yöntemi virüse maruziyetten (temastan) kaçınmaktır.

- Bu virus insandan insana bulaşmaktadır.

- Covid-19 Yeni koronavirüs hastalığından kendinizi ve başkalarını nasıl koruyabileceğiniz konusunda Sağlık Bakanlığı, Halk Sağlığ1 Genel Müdürlüğü ve hekiminiz/hemşireniz tarafından verilen bilgileri dikkatlice takip edin ve uygulayın.

\section{KENDINiZi KORUMANIN BELLİ BAŞLI ADIMLARI}

\section{EVDE KALIN !!}

- Gerekli durumlar dişında dışarı çıkmayınız.

- Kalabalık yerlerde kesinlikle bulunmayınız.

- Toplu taşıma kullanmayınız.

- Birlikte yaşadığınız kişiler de mecbur olmadıkça dışarı çıkmamalıdır.

\section{ELLERİIIZI SIK SIK YIKAYINIZ !!}

- Su ve sabunla en az 20 saniye (20'ye kadar sayarak) el yıkayını.

- Özellikle halka açık yerlerde bulunduktan sonra ellerinizi yıkayınız.

-Asansör, kapı kolu, wc vb. ortak kullanılan alanlara dokunduktan sonra ellerinizi su ve sabunla yeterli sürede ve sık sık yıkayınız.

- Siz ya da etrafınızdaki insanlar öksürdükten ya da aksırdıktan sonra ellerinizi yıkayınız.

- Su ve sabun yanınızda mevcut değilse, en az \%70 alkol içeren el antiseptiğiyle ellerinizi ovalayınız.

- Bu antiseptik ile ellerinizin tüm yüzeyini kaplayacak şekilde elleriniz kuruyana kadar ellerinizi ovalayınız.

-Yıkanmamış elleriniz ile ağız, burun ve gözlerinize dokunmayınız. 


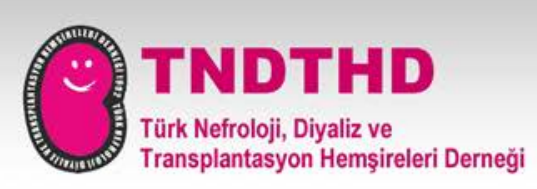

\section{EL YIKAMA VE (ALKOL BAZLI) EL DEZENFEKTANLARI KULLANMA BROŞÜRÜ}

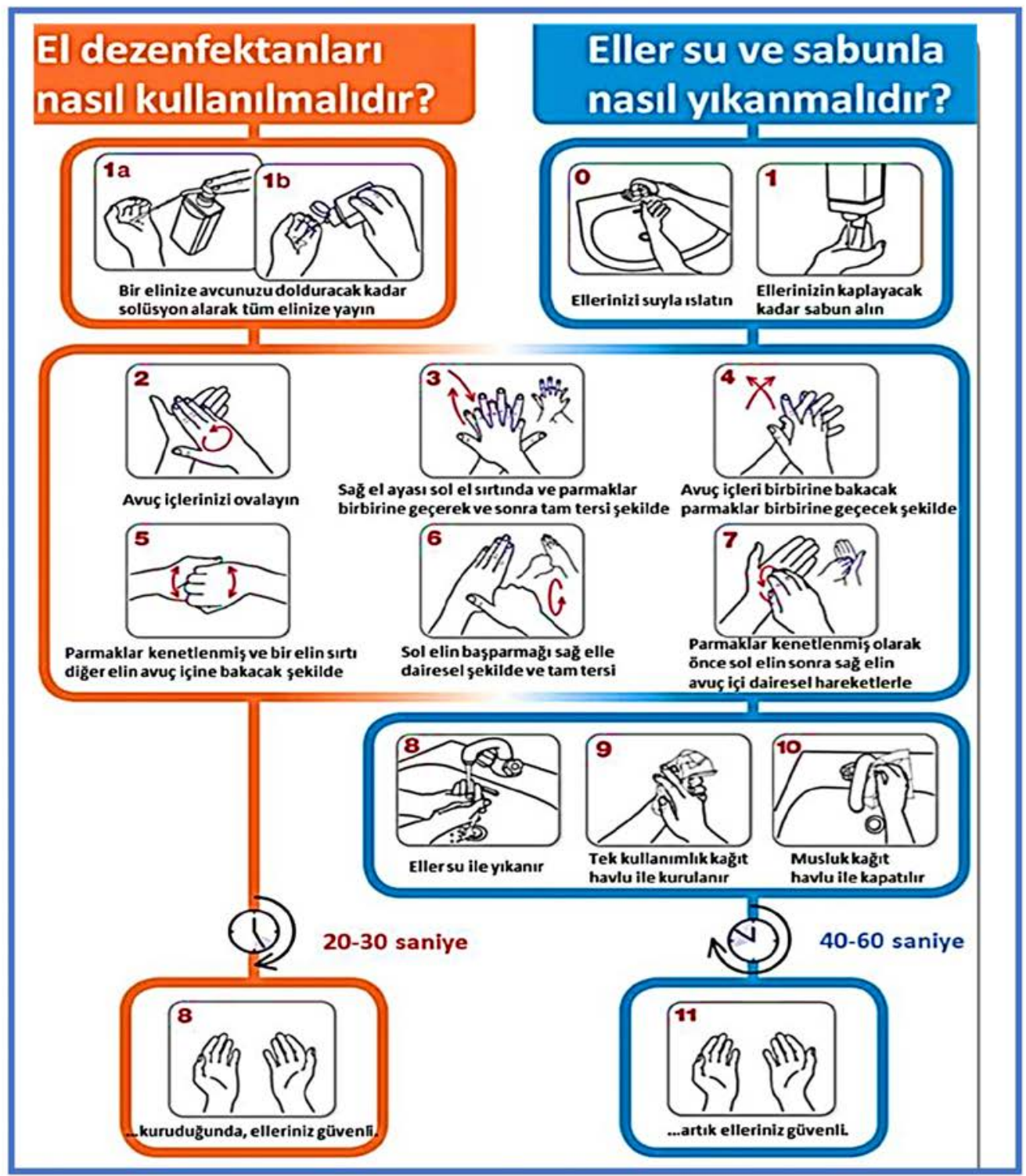

Kaynak 4. https://www.who.int/images/default-source/health-topics/coronavirus/riskcommunications/hand-cleaning/handrub.jpg?sfvrsn=e9b44b62_2 


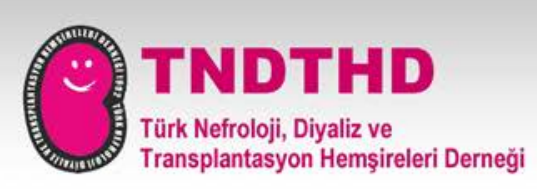

\section{SOSYAL MESAFE NEDİR VE NASIL KORUNULUR}

\section{Sosyal mesafe}

Bireyler arasındaki fiziksel teması en aza indirmeyi ve böylece enfeksiyon olasılığını azaltmak amacıyla kullanılır.

İnsanların buluştuğu yada toplandığı yerlerden uzak durmak, toplu taşıma araçlarından (örneğin otobüs, metro, minibüs, taksi birlikte binilen araba) kaçınmak ve diğer kişilerden uzaklığı korumak (3-4 adım) anlamına gelir.

Sosyal mesafeyi korumak için kişilerle (aile bireyleriniz dahil) aranıza her zaman 3-4 adım mesafe bırakınız ve dışarıda iseniz maskenizi takınız.

\section{Yakın Temastan Kaçınınız!!!}

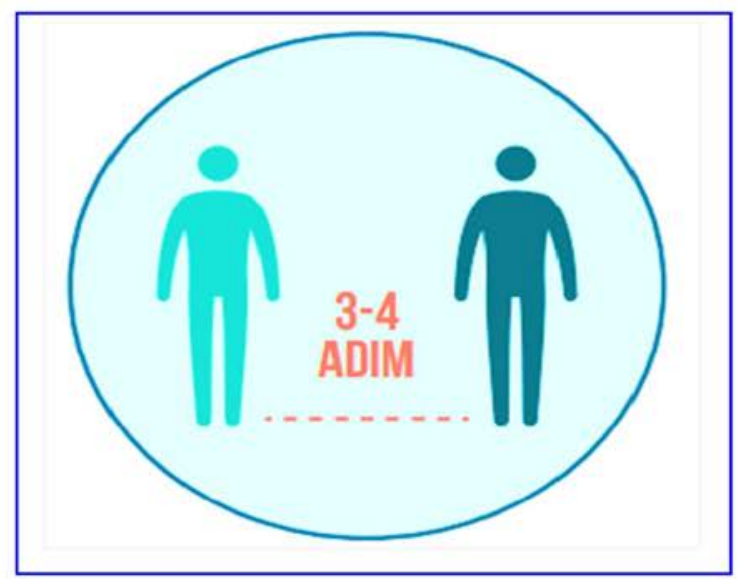

Kaynak 3: T.C. Sağlık Bakanlığı Halk Sağlığı Genel Müdürlüğü Yeni Koronavirüs Hastalığı (COVID19), Erişim: 11.04.2020 https://covid19bilgi.saglik.gov.tr/tr/

6: ECDC REPORT Guidance for social distancing measures aimed at minimising the spread of SARS-CoV-2 23 March 2020, Erişim tarihi: 07.04.2020

https://www.ecdc.europa.eu/sites/default/files/documents/covid-19-socialdistancing- 


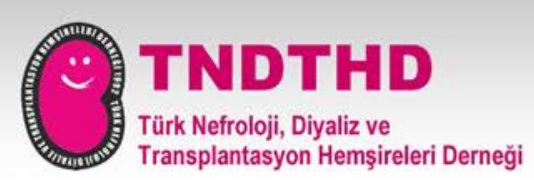

\section{Öksürme ve Hapşırma!!}

- Öksürme ve hapşırma sırasında burnunuzu ve ağzınızı tek kullanımlık kağıt mendil ile kapatınız.

- Kağıt mendiliniz yoksa dirsek içini bu amaçla kullanınız.

- Ellerinizi en kısa sürede su ve sabunla yıkayınız.

- Su ve sabun bulamıyorsanız, en az \%70 alkol içeren el antiseptiği ile ellerinizi ovalayınız.

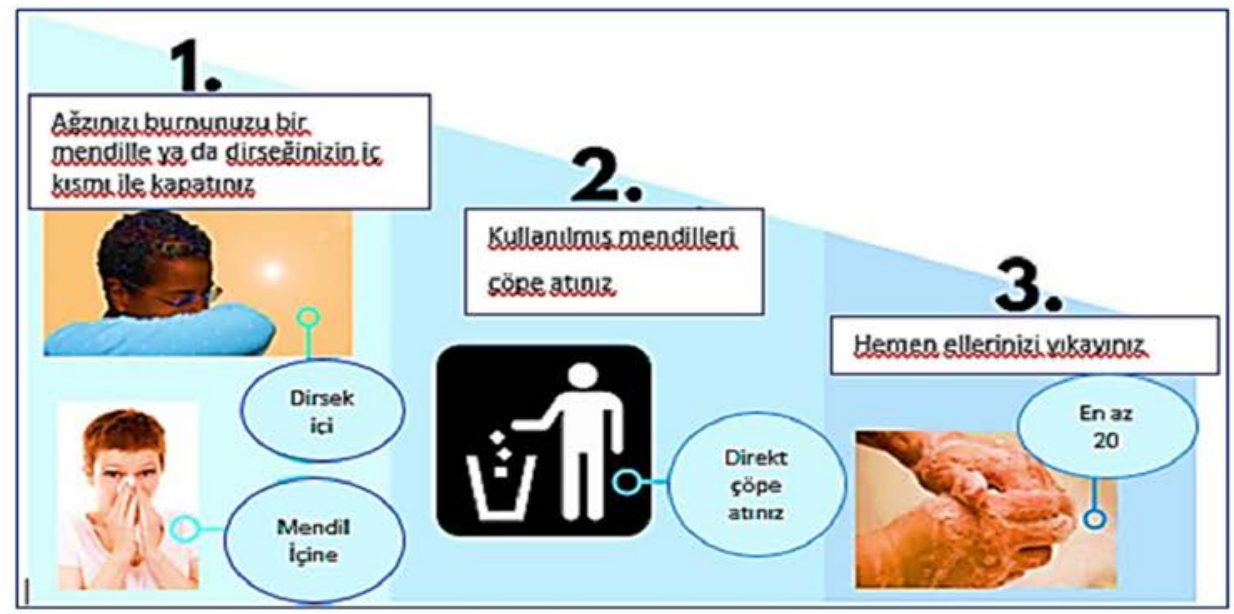

Şekil-1: 1.2 ve 3. Adımları öksürme ve hapşırmadan sonra uygulayınız.

Kaynak 7.AST.Power2Save one transplant for life. Coronavirus disease 2019 (COVID-19): FAQs for transplant candidates and recipients Erişimhttps://www.myast.org/coronavirus-disease-2019covid-19-frequently-asked-questions-transplant-candidates-and-recipients

\section{MASKE KULLANIMI !!}

- Tıbbi/Cerrahi maske olarak adlandırılan maskeleri kullanabilirsiniz.

- N95 olarak adlandırılan özellikli maskeleri sizler kullanmıyorsunuz.

- Evden dışarıya çıktığınızda mutlaka bu tıbbi/cerrahi maskeyi kullanınız.

- Sizinle birlikte kalan kişilerde dışarıya çıktıklarında maske kullanmalıdır.

- Maskenin nasıl takılıp çıkarılması ile ilgili ayrıntılı bilgi aşağıda gösterilmiştir. 


\section{TNDTHD}

Türk Nefroloji, Diyaliz ve

Transplantasyon Hemşireleri Derneği

\section{TIBBİ/CERRAHI MASKE KULLANIMI}

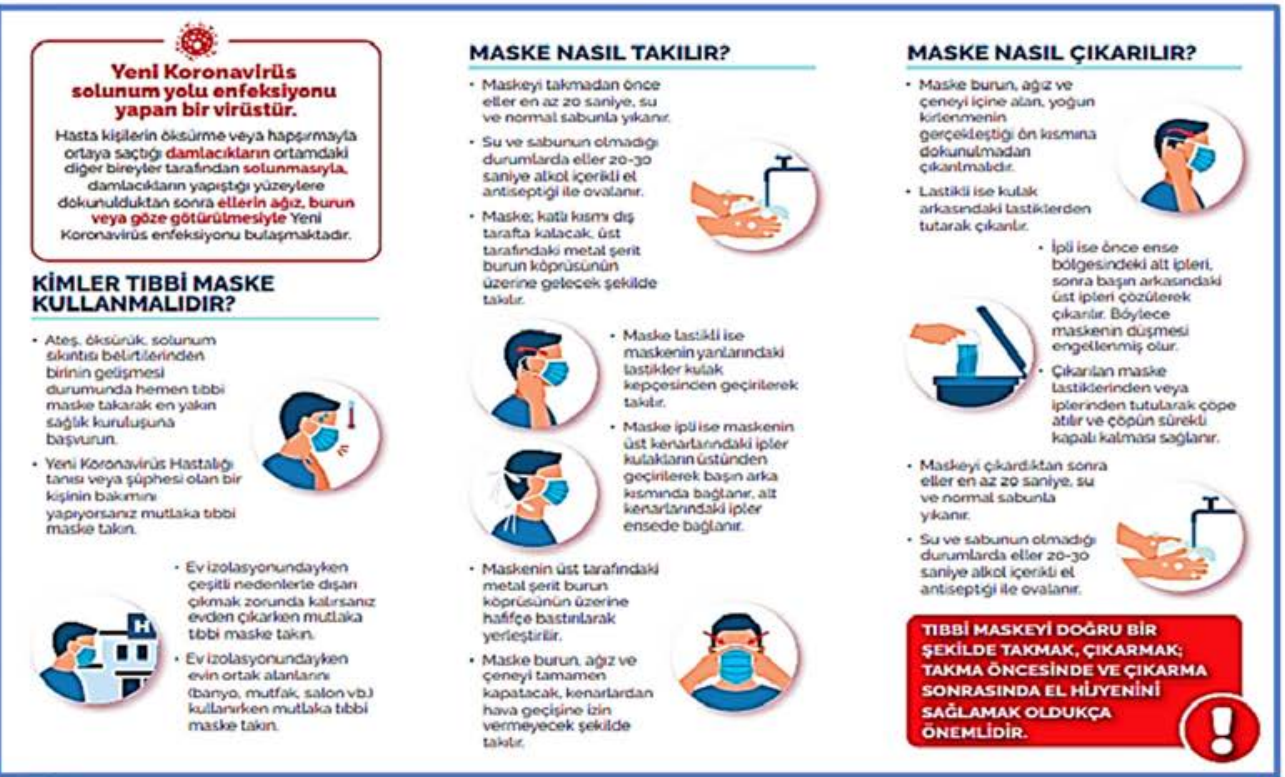

\section{TIBBI MASKE KULLANIMI SIRASINDA DIKKAT EDILMESI}

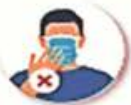

Tobimabcrintean incon $\lim$. dokunumamanatide.

Karara dokunulums we nomatsibens bermicivana sald

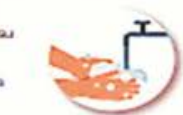

80

Tooimater

Whari, ncerdant

deglistiametidit.

Tobi masholct
kesheate ortak

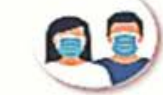

i)

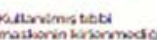

aivincis biok

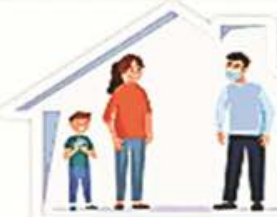

\section{6}

Dışarıda herkesin tıbbi maske takması zorunludur

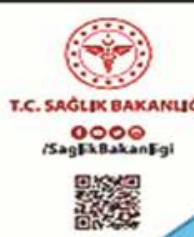

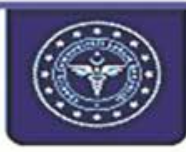

YENI KORONAVIRÜS (COVID-19)

\section{TIBBI MASKE}

KULLANIMI 


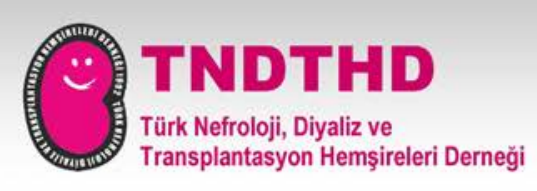

\section{TEMIZLIKK VE DEZENFEKSIYON!!}

-Dokunduğunuz her yeri gün içinde sık sık deterjanla temizleyiniz.

- Gün içinde en fazla dokunulan yerler; Masa, sandalye, koltuk, kapı kolları, 1ş1k prizi, anahtarlık, tezgahlar, telefonlar, tuvaletler, lavabolar, musluklar, kumandalar vb. yerleri sık sık temizleyiniz.

- Kirlenme olduysa kirlenen eşya ya da yüzeyi hemen temizleyiniz.

-Yumuşak gözenekli yüzeyleri (halı, perde, koltuk vb.) görünür bir kirlenme varsa deterjanla temizleyiniz. Mutlaka kurumasinı sağlayınız.

- Havlu, çamaşır, çarşaf gibi tekstil ürünlerinin temizliği sırasında silkelemekten kaçınınız, bu eşyaları çamaşır makinesinde mümkün olan en sicak 1sida (en az 60 derecede) yıkayınız ve kuruttuktan sonra ütüleyiniz.

- Dışarıda kullandığınız kıyafetleri eve girer girmez çıkarınız, dışarıdan içeriye ayakkabı sokmayınız. Dış giysi olarak kullan-at şeklinde şeffaf yağmurluk vb. giysiler kullanabilirsiniz.

- Hasta kissilerin, kirli giysilerini eldiven kullanarak tutunuz ve ayrı olarak (mümkünse bir file içinde) mümkün olan en sıcak ısıda yıkayınız.

- Eldiveninizi çıkardıktan sonra da ellerinizi en az 20 sn süre ile su ve sabunla yıkayınız.

\section{TEMİZLIK/DEZENFEKSIYYN İÇİN !!}

Günlük ev temizliğinde çamaşır suyu çözeltisi kullanabilirsiniz.

\section{Çamaşır suyu çözeltisi hazırlamak için:}

$\checkmark \quad 3$ litre suya 3 yemek kaşığı ya da bardağın 1/3'ü kadar çamaşır suyu

$\checkmark$ Ya da 1 litre suya 4 çay kaşı̆̆ı çamaşır suyu ekleyerek elde edebilirsiniz. 


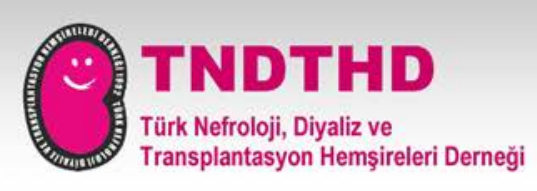

- Kullandığınız çamaşır suyunun (üretici firmanın) uygulama ve uygun havalandirma talimatına uyunuz.

- Kullandığınız ürünün son kullanma tarihini kontrol ediniz.

- Ev tipi çamaşır suyunu asla amonyak ya da başka bir hiçbir temizleyici ile karıştırmayınız.

- Alkol solüsyonu kullanacak iseniz; En az \%70 alkol içeren solüsyon ile kullandığınız yüzeyleri dezenfekte ediniz.

\section{ETRAFINIZDA HASTA BİRI VARSA !!}

- Etrafınızda hasta biri varsa mümkünse aynı evde yaşamayınız.

- Evinizi ayırmanız mümkün değilse;

$\checkmark$ Bu kişiler ile tuvalet, banyo ve yatak odanızı, havlu, fırça gibi ortak kullanılan malzemeleri ayırınız.

$\checkmark$ Hasta olan kişinin, evde sizden ayrı olarak farklı bir odada kalmasını sağlayınız.

$\checkmark$ Yiyeceklerinizi ayırınız.

$\checkmark$ Bu kişilerin tabak, bardak, kaşık, çatal, bıçak gibi yemek yeme malzemelerini yıkarken bir eldiven kullanınız ya da bulaşık makineniz var ise makinede yıkayınız.

$\checkmark$ Hasta olan kişinin çöplerini ayrı bir torbada toplayınız.

$\checkmark \mathrm{Bu}$ çöpler de atılırken eldiven kullanınız ve çöp torbasının ağzını sıkıca kapatınız. 


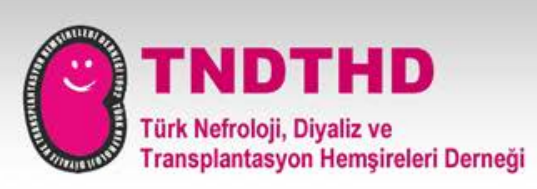

\section{EV DIYYALİİ HASTASI OLARAK YAPMANIZ VE DIKKKAT ETMENIZ GEREKENLER}

Diyaliz Merkeziniz, ev diyalizi hastalarının tedavilerine evde devam edebilmesi için ihtiyaç duydukları tüm malzemelere sahip olmaları için gereken organizasyonu sağlamaktadır.

Evde diyaliz hastasıysanız, bağlı olduğunuz hastanenin/diyaliz merkezinin sağlık personeli tarafından gerekli görüldüğü şekilde ev ziyaretleriniz planlanacaktır.

İhtiyacınız olduğunda evden ayrılmadan mümkün olduğunca destekleyici yardım veya diğer (telefonla/görüntülü görüşme) elektronik haberleşme sistemlerini kullanarak yardım almalısınız.

COVID-19 Yeni koronavirüs hastalığ 1 olan kişilere olası temas1 azaltmak için, ev diyaliz hastalarının rutin takibinde değişiklik yapılması gerekebilir.

$\mathrm{Bu}$ nedenle salgın süresince evinizde mevcut ev diyalizi programınızı sürdürünüz, tedavinizi sürdürürken de size aşağıda sıraladığımız tavsiyelere uymanızı öneririz.

\section{1. Öncelikli olarak belirtilerinizi takip ediniz:}

\section{Kendiniz ve evinizde yaşayan tüm aile bireyleri için;}

- Günlük olarak Ateş takibi yapınız,

- Geçmeyen ve ilerleyici öksürük ,

- Nefes darlığ1,

- Göğüste baskı ya da ağrı varlığı,

- İshal,

- Uyku hali ve uyanamama gibi belirtilerin varlı̆g tek başına önemli olmamakla birlikte diğer belirtiler ile birleşmesi durumunda önem taşımaktadır. 


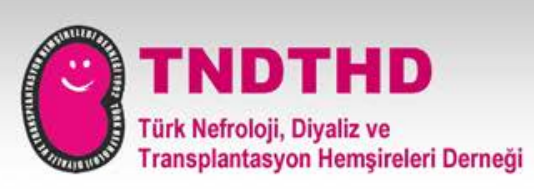

* Yukarıda sayılan belirtilerden herhangi birini hissettiğinizde mutlaka ev diyaliz hemşirenizi arayınız. !!!

2. Mecbur kalmadıkça kalabalık ortamlara girmeyiniz:

- İlaçlarınızı toplu temin ediniz. Sağlık bakanlığı tarafından süresi dolan ilaçlarınızın raporları uzatılmıştır. Evinizde bulunan tüm ilaçlarınızı kontrol ediniz ve evinizden uzun süre çıkmayacak şekilde hesaplayarak doktorunuza yazdırınız. (biten ve eksilen ilaçlarınızı sayınız )

- Aylık kan tahlilleriniz için kan numunelerinizi kargoya/ diyaliz merkezinin görevlisine teslim ederken mutlaka tıbbi/ cerrahi maskenizi takınız veya yakınınız ile gönderiniz.

- Market ve benzeri ihtiyaçlarınız için: İhtiyaç listenizi uzun süre yetecek şekilde evden çıkmadan listeleyiniz ve mümkünse sabah erken saatlerde alışverişinizi tamamlayınız/aile bireylerinden yardım isteyiniz.

- Olabildiğince tüm insanlar ile aranızda en az 3-4 adım sosyal mesafeyi koruyunuz.

- Toplu taşıma araçlarını kullanmamaya çalışınız, Dışarı çıkmak zorunda kaldığınızda özel aracınız varsa aile bireylerinden yardım isteyiniz.

* Dışarı çıktığınızda mutlaka tıbbi/cerrahi maske takınız.

Dışarıda el hijyeni sağlamak için el dezenfektanı kullanınız.

Evinize geldiğinizde ellerinizi yıkamayı ve tüm

kıyafetlerinizi değiştirmeyi unutmayınız.

3. Vücut direncinizi koruyunuz:

- Beslenmenize dikkat ediniz. Günde 1 portakal yarım elma kadar $\mathrm{C}$ vitamini içeren meyve tüketiniz.

- Günde sekiz saat uyumaya çalışınız. Yeteri kadar dinleniniz. 


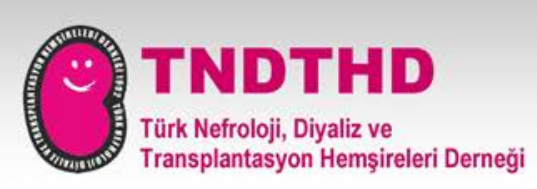

- Soğuktan korununuz.

- Doktorunuz önermiş ise C vitamini, B vitamini ve Folik asit kullanabilirsiniz.

\section{Diyaliz malzemelerinin temizliğine dikkat ediniz:}

- Hastanenizden ya da diyaliz merkezinizden imkânlar ölçüsünde uzun süre yetecek kadar malzeme isteyiniz.

- Malzemelerinizi evinizin içine direkt kabul etmeyiniz.

- Tüm malzemelerinizi çamaşır sulu bez ile silerek depoladığınız alana taşımalısınız.

- Bulunduğunuz ortamı her gün ve sık sık havalandırınız.

\section{Diğer Öneriler}

- Acil bir durum olmadikça hastaneye ve diyaliz merkezine gitmeyiniz.

- Kontrol ya da başka bir durum için kliniğe gitmek zorundaysanız, kliniğin diyalize giriş çıkış saatleri haricindeki yoğunluğun azaldığ 1 saatleri tercih ediniz.

- Merak ettiğiniz sorularda Ev Diyaliz Hemşirenizi mutlaka arayınız.

- Ev Diyaliz hastaları sık sık el hijyeni, solunum hijyeni, öksürük görgü kuralları, enfeksiyon kontrol önlemleri ve sosyal mesafenin önemi, maske kullanımı gibi COVID-19 Yeni Koronavirüs Hastalığını önlemeye yönelik tedbirler konusunda ev diyaliz hemşiresi tarafından eğitilecektir.

- Diyaliz merkezine randevuya gelmeden önce ateş ve COVID-19 Yeni Koronavirüs Hastalığı belirtileri açısından kendinizi değerlendiriniz, ateş veya herhangi bir belirtiniz mevcutsa, hemen ev diyaliz hemşirenize mutlaka bilgi veriniz, sağlık durumunuza göre ya bir sağlik kurumuna başvurunuz ya da merkeze ziyaretinizi başka bir tarihe erteleyiniz. 


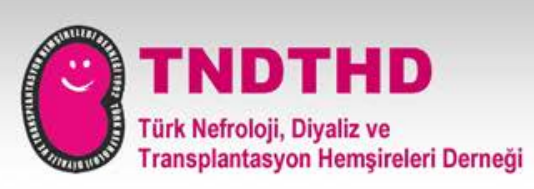

\section{SIK SORULAN SORULAR}

Soru: Diyaliz Hastasıyım, sokağa çıkma yasağı ve sosyal izolasyon ile ilgili tedbirler beni etkiliyor mu?"

Cevap: COVID-19 Hastalığının bulaşması açısından riskiniz yüksektir ve Sağlık Bakanlığının sosyal mesafe kuralı sizin içinde geçerlidir, bekleme salonunda, tedavi salonunda sizin için yapılan düzenlemelere sıkı sıkıya uymalısınız, acil durumlar dışında sokağa mecbur kalmadıkça çıkmamalısınız, mecbursanız sosyal mesafeye dikkat ediniz (3-4 adım) ve mutlaka tıbbi maskenizi takınız.

Soru: Yüksek tansiyonum var, tansiyon ilaçlarımı kesmeli veya değiştirmeli miyim?

Cevap: Tansiyon ilaçlarının bu hastalığın seyrini olumsuz etkilediğine dair bilgi kanıtlanmış değildir. Şu anda, belirli bir tansiyon ilaç grubunun bu hastalığı nasıl etkilediğine dair bir kanıt bulunmamaktadır. Başta tansiyon ilaçlarınız da dahil olmak üzere tüm reçeteli ilaçlarınıza diyaliz hekiminizin size reçete ettiği şekilde devam etmeniz ve ilaçlarınızı hekiminizle görüşmeden kesinlikle kesmemeniz önemlidir.

Soru: Diyaliz hastas1 olarak seyahat etmemde bir sakınca var m1, kendi merkezimden başka bir diyaliz merkezine gidebilir miyim?

Cevap: Sağlık Bakanlığının talimatları gereği Diyaliz Hastalarının bu salgın hastalık dönemi boyunca kendi tedavi gördükleri merkez dışında bir merkezde tedavi görmelerine sınırlama getirilmiştir. Sizin, ailenizin ve tedavi gördüğünüz sağlık merkezi çalışanlarının sağlığının korunması, Covid-19 Yeni Koronavirüs Hastalığının bulaşmaması adına bu sınırlama çok önemlidir. Şu an için şehirlerarası seyahatlere çok sıkı sınırlama getirilmiştir. Başka şehirlere yasağın kaldırılıp kaldırılmadığını İç İşleri Bakan-lığının duyurularından takip edebilirsiniz. 


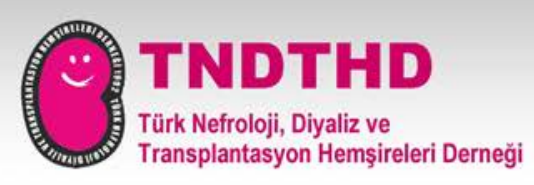

Soru: Diyaliz hastası olarak Covid-19 hastalığının bana bulaşması ile ilgili çok ciddi kaygılarım var ve korkuyorum, korku ve kaygımı azaltmak için ne gibi önerileriniz olabilir?

Cevap: Bir kriz sırasında kendinizi üzgün, stresli, şaşkın, korkmuş veya k1zgin hissetmeniz normaldir. Hepimizi tehdit eden bu belirsizlik durumuna eğer izin verirsek ruh sağlığımız da olumsuz etkilenecektir. Ruhsal sıkıntıların çarpıntı, terleme veya nefes alamama hissi gibi fiziksel sikayetlere de neden olabileceği unutulmamalıdır ki bunlar beklenen, normal vücut reaksiyonlarıdır.

\section{Kendi sağlık durumunuz veya sevdiklerinizle ilgili korkularınız ve endişeleriniz:}

- Uyku ya da yemek düzeninde değişikliklere

- Uyumakta ya da konsantre olmakta zorluğa

- Kronik sağlik sorunlarının kötüleşmesine ve

- Alkol, sigara ya da diğer ilaçların kullanımının artmasına neden olabilmektedir.

\section{Bu durumlarda güvendiğiniz insanlarla konuşmak size yardımc1 olabilir.}

- Ailenizle ve arkadaşlarınızla iletişim kurunuz.

- Arkadaşlarınızla sadece telefonla iletişime devam ediniz.

- Endişelerinizle tek başınıza mücadele etmeye çalışmayınız.

- Başkalarıyla iletişim kurarak onlardan da destek alınız. 


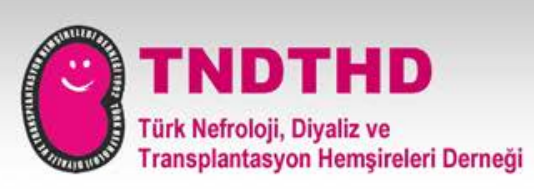

\section{SAĞLIKLI BİR YAŞAM IÇİN GENEL KURALLARA UYUN:}

1. İyi beslenin: Hastalığınız nedeniyle kısıtlanan yiyecekler haricinde dengeli besleniniz. Diyalizler arasında fazla kilo almamaya özen gösteriniz. Vücutta aşırı sıvı birikiminin özellikle akciğerlerde enfeksiyon riski oluşturduğunu unutmayınız.

2. İyi uyuyun: Uyumadan önce zihninizi rahatlatmak için müzik dinleyin, kitap okuyun, sevdiklerinizi, geçmişteki güzel anılarınızı veya sizi mutlu edecek şeyleri düşününüz.

3. Egzersiz yapın: Kalabalık ortamlardan uzak durmak, soğuktan korunmak ve kendinizi aşırı yormamak koşuluyla yürüyüş gibi hafif egzersiz yapınız, Rahatlamak için kendinize zaman ayırınız, böylece bir süre sonra yoğun duygular geçecektir.

- Haberleri izlemeye, okumaya ya da dinlemeye mola veriniz.

- Tekrarlayan biçimde krizi duymak ve görüntüleri görmek üzücü olabilir.

- Normal yaşamınıza dönmek için hoşlandığınız diğer bazı etkinlikleri yapmaya çalışınız.

- Duygularınızla başa çıkmak için sigara, alkol veya diğer ilaçlardan uzak durunuz. Bunalmış hissediyorsanız hekiminizle paylaşın ve önerilerini alınız.

- Güvenilir kaynaklardan ve gerçek bilgiyi almaya çalışınız.

- Makul önlemler alabilmeniz için riskinizi doğru bir şekilde belirlemenize yardımcı olacak bilgileri dikkatlice takip ediniz.

- Gerçek dişı haberlerden uzak durunuz.

- Sizi ve ailenizi üzecek medya yayınlarını dinlemeyiniz ve izlemeyiniz. 


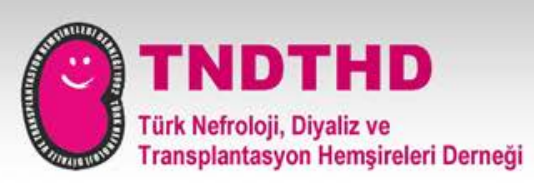

\section{Kaynaklar}

1. CDC-Centers of Disease Control and Prevention, Coronavirus Disease 2019 (COVID-19), Erişim: https://www.cdc.gov

2. ERA/EDTA COVID-19 guideline, Erişim: https://www.era-edta.org/en/ covid-19-news-and-information/

3. T.C. Sağlık Bakanlığı Halk Sağlı̆̆1 Genel Müdürlüğü Yeni Koronavirüs Hastalığı (COVID-19), Erișim: https://covid19bilgi.saglik.gov.tr/tr/

4. WHO-World Health Organization, www.who.int.Erişim:https://www.who. int/images/default-source/health-topics/coronavirus/risk-

communications/hand-cleaning/handrub.jpg?sfvrsn=e9b44b62_2

5. https://covid19bilgi.saglik.gov.tr/depo/afisler/COVID19-TIBBI-MASKEKULLANIMI-29X20-2KIRIMLI-BROSUR.pdf.pdf Erişim Tarihi: 07.04.2020

6. ECDC REPORT Guidance for social distancing measures aimed at minimising the spread of SARS-CoV-2 23 March 2020, Erişim tarihi: 07.04.2020 https://www.ecdc.europa.eu/sites/default/files/documents/ covid-19-social-distancing-

7. AST.Power2Save one transplant for life. Coronavirus disease 2019 (COVID19): FAQs for transplant candidates and recipients Erişimhttps: //www.myast.org/coronavirus-disease-2019-covid-19-frequently-askedquestions-transplant-candidates-and-recipients

8. WHO: Coping with stress during the 2019-nCoV outbrake- https://www. who.int/docs/default-source/coronaviruse/coping-with-stress.pdf?sfvrsn= 9845bc3a_2 https://www.cdc.gov/coronavirus/2019-ncov/daily-life-coping/ managing-stress-anxiety.html

9. Kidney Care UK: Managing anxiety and fear.https://www.kidneycareuk.org/ news-and-campaigns/coronavirus-advice/managing-anxiety-and-fear/

10. Türk Psikiyatri Derneği: Koronavirüs hastalı̆ı salgını sırasında ruh sağlığı stresle baş etme- 13 Mart 2020, https://www.psikiyatri.org.tr/ 2147/ koronavirus-hastaligi-salgini-sirasinda-ruh-sagligi-ve-stresle-bas-etme

11. Kidney Care UK:https://www.kidneycareuk.org/news-and-campaigns/ coronavirus-advice/\#dialysis Erişim tarihi:07.04.2020

12. Davita Kidney Care: https://www.davita.com/covid-19-information 


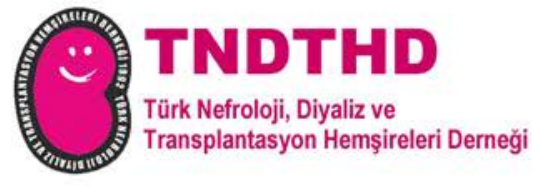

\author{
TÜRK NEFROLOJI, \\ DIYALIZ VE TRANSPLANTASYON \\ HEMŞiRELERI DERNEĞi
}

\title{
ORGAN NAKLI OLAN HASTALARA YÖNELİK COVID-19 KORONAVİRÜS HASTALIĞI REHBERİ
}

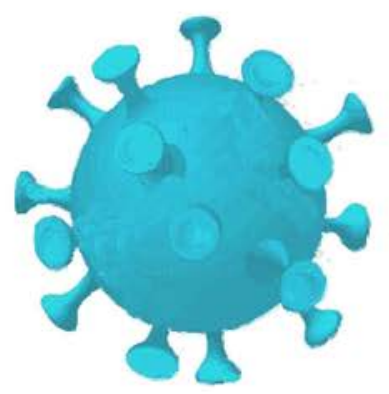

07.05 .2020 
COVID-19

Komisyon Üyeleri

\section{Başkan \\ Ayten KARAKOÇ}

\section{Nermin ERDOĞAN}

THD COVID-19 Komisyon Üyesi ve Hemodiyaliz Rehberi Sorumlu Yazart

\section{Yaprak SARIGÖL ORDİN}

Organ Nakli Rehberi Sorumlu Yazan

\section{Güler NASUHBEYOĞLU}

Periton Diyaliz Rehberi Sorumlu Yazan

\section{Fatma ERSOY}

Ev Hemodiyalizi Rehberi Sorumlu Yazan

\section{Gülseren PEHLIVAN \\ Sevel YILDIZ Sevginar ŞENTÜRK}

\section{Tasarım}

ninetasarim@gmail.com 


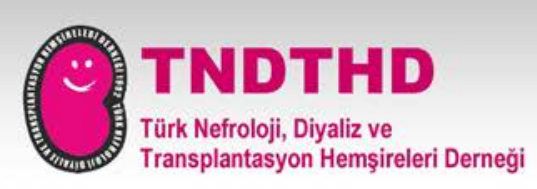

\section{ORGAN NAKLI OLAN HASTALARA YÖNELİK COVID-19 KORONAVIRÜS HASTALIĞI REHBERİ}

Bu rehber, tüm dünyayı etkisi altına alan ve çok ciddi can kaybına neden olan COVID-19 Yeni Koronavirüs Hastalığıyla mücadelede hali hazırda Organ Nakli Olmuş hastalarımızın ve onlara bakım veren hasta yakınlarının, doğru bilgilendirilmesi ve gerekli korunma önlemlerini alması için Türk Nefroloji, Diyaliz ve Transplantasyon Hemşireleri Derneği COVID-19 Komisyonu tarafından hazırlanmıştır.

Rehber hazırlanırken, ağırıklı olarak Dünya Sağlık Örgütününün (DSÖ) önerileri, uluslararası kılavuzlar ve Sağılı Bakanlığı Bilim Kurulu Kararlarından yararlanılmış, güncel ve bilimsel gelişmeler ışığında gözden geçirilmiştir.

Eşi görülmemiş bir dönemle karşı karşıyayız. Siz Organ Nakli olmuş hastalarımızı dinlemek ve desteklemek için burada olduğumuzu lütfen unutmayın; yalnız değilsiniz!

Hazırlamış olduğumuz rehberde, sizin ve sevdiklerinizin sağlıklı ve güvende kalmasına yardımcı olacak bilgileri ve kaynakları, ayrıca Sık Sorulan Sorulara verilen yanıtlarımızı bulabilirsiniz.

Saygılarımızla

Türk Nefroloji, Diyaliz ve Transplantasyon Hemşireleri Derneği

COVID-19 Komisyonu 


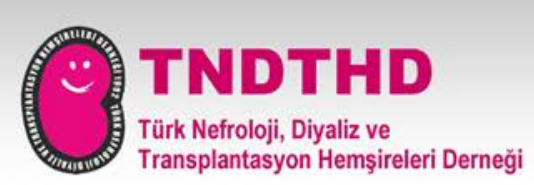

\section{ORGAN NAKLI OLAN HASTALARA YÖNELIK COVID-19 KORONAVIRÜS HASTALIĞI REHBERI}

\section{COVID-19 (Yeni Koronavirüs Hastalığı) Nedir?}

Yeni koronavirüs (COVID-19), ilk olarak Çin'in Wuhan şehrinde 2019 Aralık ayının son günlerinde solunum yolu belirtileri (ateş, öksürük, nefes darlı̆̆ı) ile gelişen bir grup hastada yapılan araştırmalar sonucunda tanımlanan bir virüstür.

Daha sonra bu virüs Çin Halk Cumhuriyeti'nin diğer eyaletleri ve sonrasında da tüm dünyaya yayılmıştır. Dünya Sağlık Örgütü 12 Mart 2020 tarihinde COVID-19'a bağlı ortaya çıkan koronavirüs hastalığını pandemi (salgın) olarak ilan etmiştir.

\section{COVID-19'un (Yeni Koronavirüs Hastalığ1) Belirtileri Nelerdir?}

COVID-19 koronavirüs hastalığının orta düzeyde ve şiddetli semptomları (belirtileri) vardır. Hastalık belirtileri virüse maruziyet (temas) sonrası 2-14 gün içinde görülmektedir.

Bu Belirtiler; Ateş, koku ve tat kayb1, öksürük, grip benzeri belirtiler (kas ağrısı, yorgunluk gibi) bulantı ve kusma, ishal ve karın ağrısı, solunum sıkıntısı, şiddetli olgularda; zatürre, ağır solunum yetmezliği ve ölüm gelişebilmektedir.

\section{COVID-19 (Yeni Koronavirüs Hastalığı) Nasıl Bulaşır?}

- Hasta bireylerin öksürmeleri, aksırmaları ile ortama saçılan damlacıkların solunması ile bulaşır.

- Hastaların solunum parçacıkları ile kirlenmiş yüzeylere dokunulduktan sonra ellerin yıkanmadan yüz, göz, burun veya ağıza götürülmesi ile de virüs alınabilir.

- Kirli ellerle göz, burun veya ağıza temas etmek risklidir. 


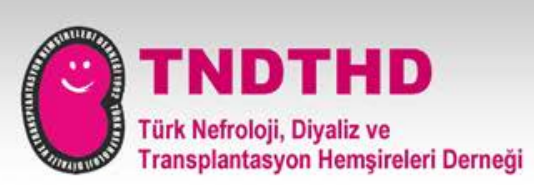

4. Kimler COVID-19'un (Yeni Koronavirüs Hastalığı) Şiddetli Seyretmesi Açısından Risk Grubundadır?

COVID-19 yeni bir hastalıktır ve bu hastalığın şiddetli seyretmesine neden olan risk faktörleri hakkında sınırlı bilgi vardır. Elimizde var olan bilgilere ve klinik deneyimlere göre;

\section{COVID-19 hastalığının şiddetli seyretmesi açısından yüksek riskli hastalar;}

- 65 yaş üstü insanlar

- Uzun süre huzurevinde kalan insanlar

- Ciddi sağlık sorunu olan herhangi bir yaş döneminde olan kişiler

- Astım ya da kronik akciğer hastalığı olanlar

- Ciddi kalp hastalığı olanlar

- Bağışıklık sistemi baskılanmış hastalar

- Kanser tedavisi gören hastalar

- Sigara içenler

- Kemik iliği ya da organ nakli olan hastalar

- İyi kontrol edilememiş AIDS hastaları

- Uzun süre kortizon ya da bağışıklık sistemini baskılayan ilaç kullanan hastalar

- Beden kitle indeksi 40 ve üstü olan kişiler (şişman hastalar)

- Diyabeti (şeker hastalığı) olan hastalar

- Kronik böbrek yetmezliği olan ve diyaliz tedavisi alan hastalar

- Karaciğer hastalığı olan hastalar

- Organ yetmezliği olan hastalardır.

Medyada görüntülenen ölüm ya da yoğun bakımdaki hastalar ile beraber akıldan çıkarılmaması gereken durum da \%80-85 oranında iyileşen hastalarımızın olduğudur. 


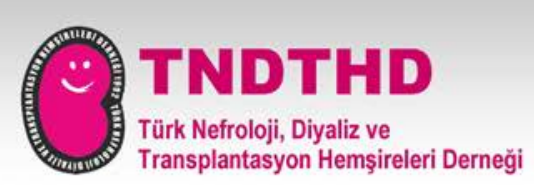

\section{COVID-19 Hastalığından Korunmak için Neler Yapılmalıdır?}

- Henüz COVID-19 Yeni koronavirüs hastalığ için koruyucu bir aşı yoktur.

-En iyi korunma yöntemi virüse maruziyetten (temastan) kaçınmaktır.

- Bu virus insandan insana bulaşmaktadır.

\section{KENDiNiZi KORUMANIN BELLİ BAŞLI ADIMLARI}

\section{EVDE KALIN !!}

- Gerekli durumlar dişında dışarı çıkmayınız.

- Kalabalık yerlerde kesinlikle bulunmayınız.

- Toplu taşıma kullanmayınız.

- Birlikte yaşadığınız kişiler de mecbur olmadıkça dışarı çıkmamalıdır.

\section{ELLERINİII SIK SIK YIKAYINIZ !!}

- Su ve sabunla en az 20 saniye (20'ye kadar sayarak) el yıkayınız.

- Özellikle halka açık yerlerde bulunduktan sonra ellerinizi yıkayınız.

- Özellikle asansör, kap1 kolu, wc vb. ortak kullanılan alanlara dokunduktan sonra ellerinizi su ve sabunla yeterli sürede ve sık sık yıkayınız.

- Siz ya da etrafınızdaki insanlar öksürdükten ya da aksırdıktan sonra ellerinizi yıkayınız.

- Eğer su ve sabun yanınızda mevcut değilse, en az \%70 alkol içeren el antiseptiğiyle ellerinizi ovalayınız.

- Bu antiseptik ile ellerinizin tüm yüzeyini kaplayacak şekilde elleriniz kuruyana kadar ellerinizi ovalayınız.

-Yıkanmamış elleriniz ile ağız, burun ve gözlerinize dokunmayınız. 


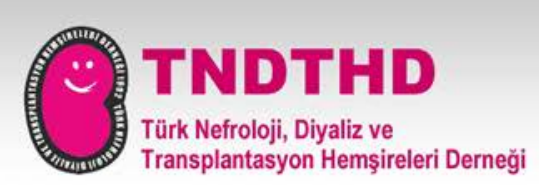

\section{EL YIKAMA VE (ALKOL BAZLI) EL DEZENFEKTANLARI KULLANMA BROŞÜRÜ}

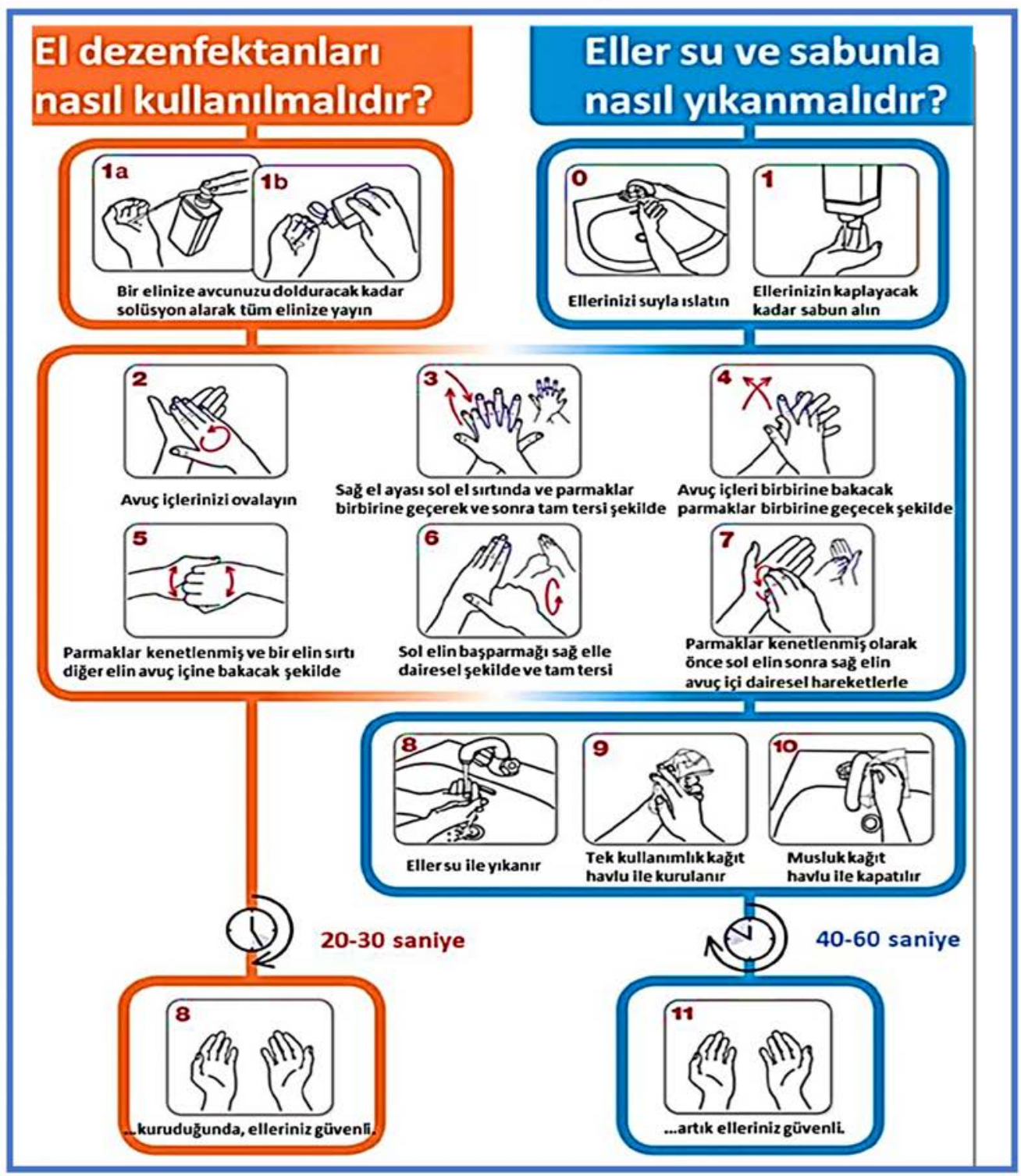

Kaynak: 6. https://www.who.int/images/default-source/health-topics/coronavirus/riskcommunications/hand-cleaning/handrub.jpg?sfvrsn=e9b44b62_2 


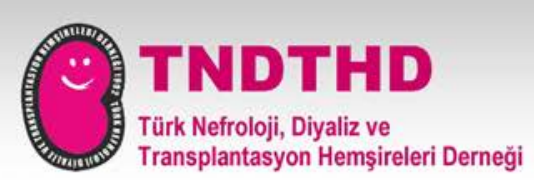

YAKIN TEMASTAN KAÇININIZ !!!

- Siz nakilli hastalarımızın nakil olduktan sonraki ilk 3 aylık döneminizde zaten yaptığınız gibi şu anda da panik yapmadan "Sosyal İzolasyon" yapmanız şart.

- Etrafınızdaki insanlar ile aranızda mesafe bırakınız (Sosyal mesafe).

- Özellikle sizin için diğer insanlar ile aranızda mesafe bırakmanız (3-4 Adım) çok önemlidir.

- Sosyal mesafe hakkında ki ayrıntılı bilgi aşağıda gösterilmiştir.

\section{SOSYAL MESAFE NEDİR VE NASIL KORUNULUR}

Sosyal mesafe: Çeşitli yollarla bireyler arasındaki fiziksel teması en aza indirmeyi ve böylece yeni enfeksiyon olasılığını azaltmak amaciyla kullanilır.

Sosyal mesafeyi korumak için kişilerle aranıza her zaman 3-4 adım mesafe bırakınız ve maskenizi takınız.

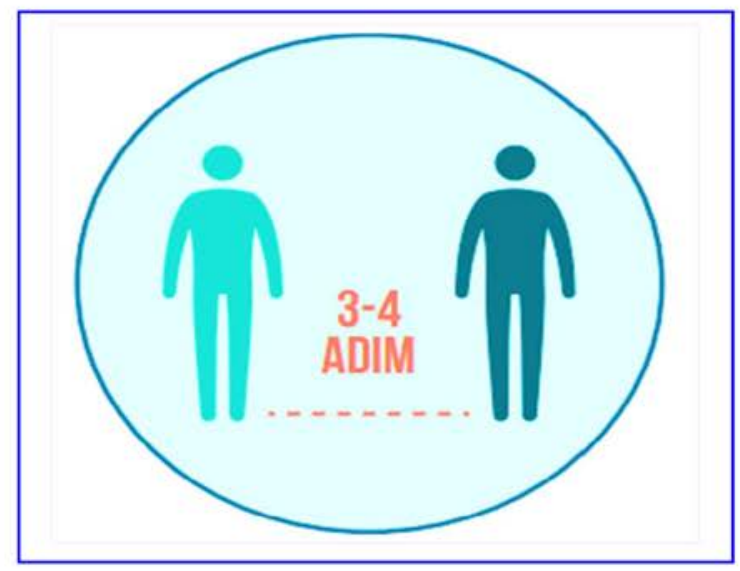

Kaynak 4: T.C. Sağlık Bakanlığı Halk Sağlığı Genel Müdürlüğü Yeni Koronavirüs Hastalığı (COVID-19), Erişim: 11.04.2020 https://covid19bilgi.saglik.gov.tr/tr/

8: ECDC REPORT Guidance for social distancing measures aimed at minimising the spread of SARS-CoV-2 23 March 2020, Erişim tarihi: 07.04.2020 https://www.ecdc.europa.eu/sites/default/files/documents/covid-19-socialdistancing- 


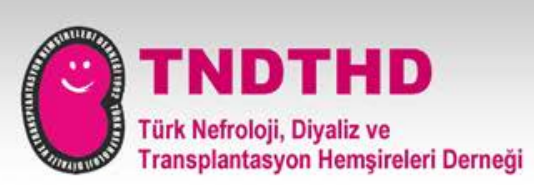

\section{DÍĞER İNSANLARI KORUMAK İÇİN !!}

- Eğer hastaysanız, evde kalın ve sağlık merkezinizi arayınız.

- Cerrahi maskenizi mutlaka takınız.

- Diğer insanlar ile temasta bulunmayınız.

\section{ÖKSÜRME VE HAPŞIRMA !!}

- Öksürme ve hapşırma sırasında burnunuzu ve ağzınızı tek kullanımlık kağıt mendil ile kapatınız.Kağıt mendiliniz yoksa dirsek içini bu amaçla kullanınız.

- Ellerinizi en kısa sürede su ve sabunla yıkayınız. Su ve sabun bulamıorsanız, en az $\% 70$ alkol içeren el antiseptiği ile ellerinizi ovalayınız.

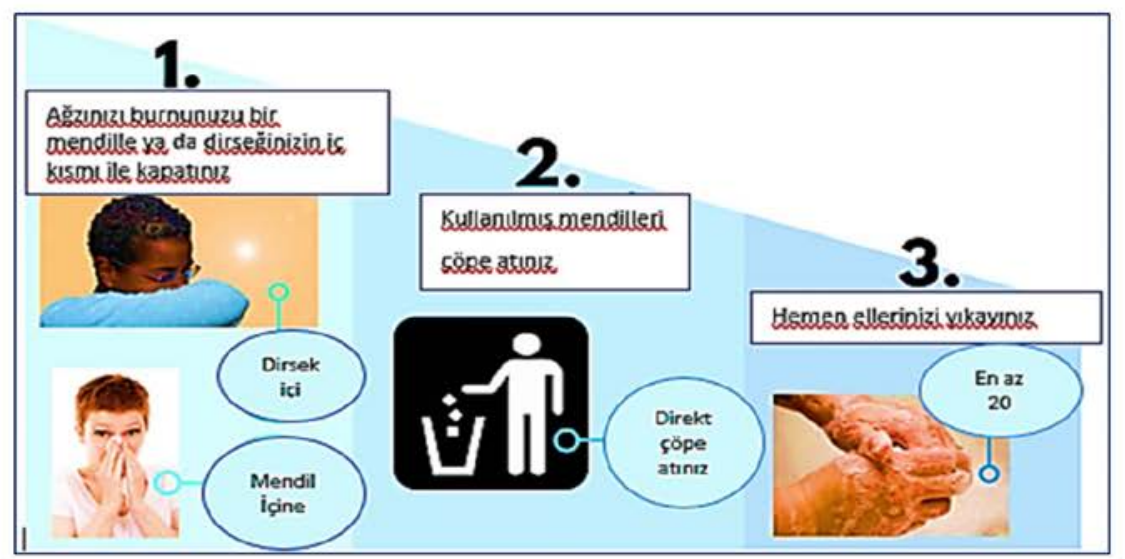

Şekil-1: 1.2 ve 3. Adımları öksürme ve hapşırmadan sonra uygulayınız.

Kaynak: 9. AST.Power2Save one transplant for life. Coronavirus disease 2019 (COVID-19): FAQs for transplant candidates and recipients Erişimhttps://www.myast.org/coronavirus-disease-2019covid-19-frequently-asked-questions-transplant-candidates-and-recipients

\section{MASKE KULLANIMI!!}

- Tibbi/Cerrahi maske olarak adlandırilan maskeleri kullanabilirsiniz.

- N95 olarak adlandırılan özellikli maskeleri sizler kullanmiyorsunuz.

- Evden dışarıya çıktığınızda mutlaka bu tıbbi/cerrahi maskeyi kullanınız.

- Sizinle birlikte kalan kişilerde dışarıya çıktıklarında maske kullanmalıdir. 


\section{TNDTHD}

Türk Nefroloji, Diyaliz ve

Transplantasyon Hemşireleri Derneği

\section{TIBBİ/CERRAHI MASKE KULLANIM BROŞÜRÜ}
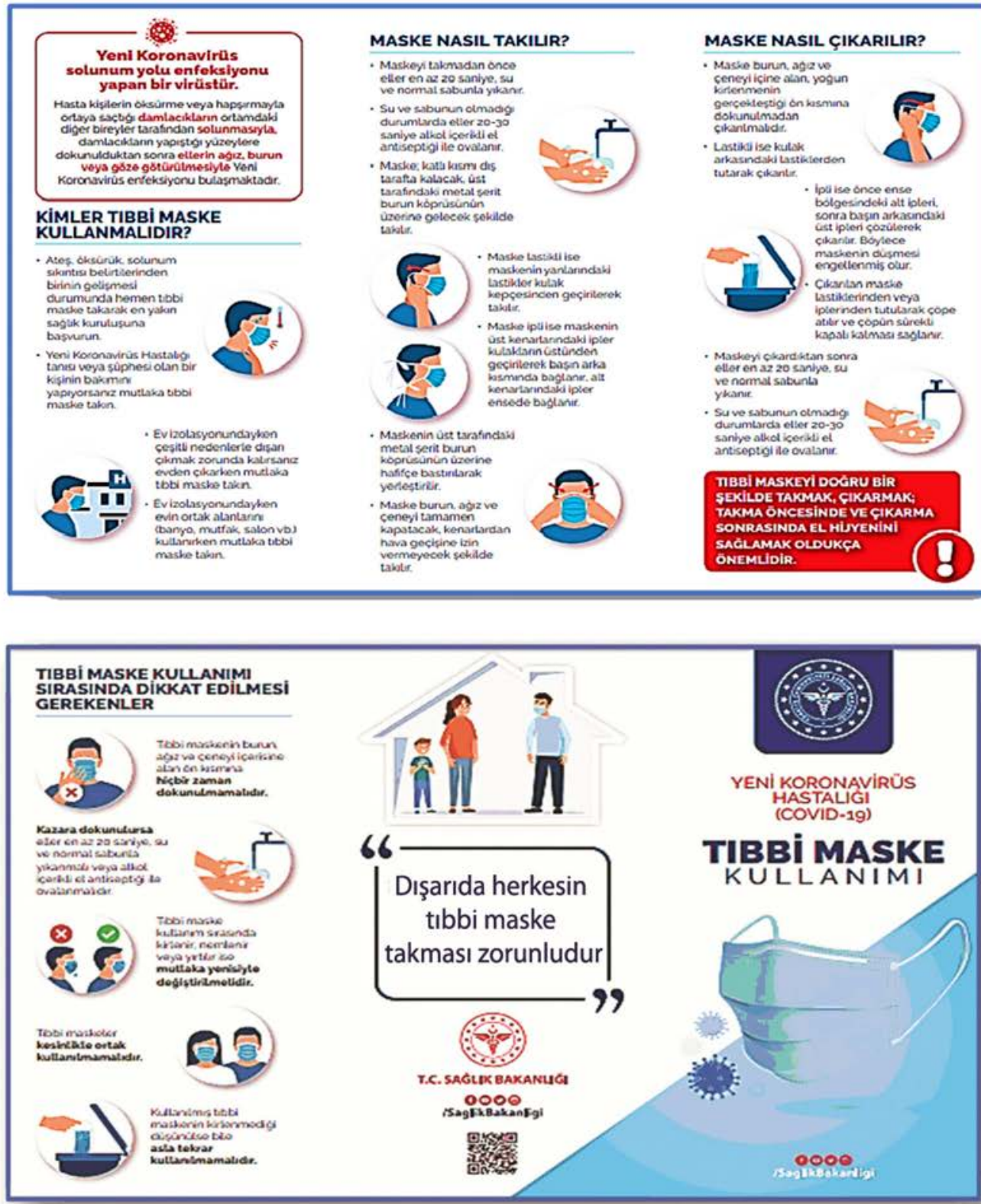


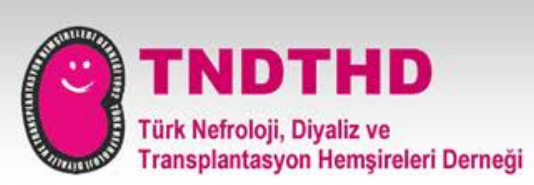

\section{TEMIZZLEME VE DEZENFEKSIYON !!}

- Dokunduğunuz her yeri gün içinde sık sık deterjanla temizleyiniz.

- Gün içinde en fazla dokunulan yerler; Masa, sandalye, koltuk, kap1 kolları, 1şık prizi, anahtarlık, tezgahlar, telefonlar, tuvaletler, lavabolar, musluklar, kumandalar vb. yerleri sık sık temizleyiniz.

- Eğer kirlenme olduysa kirlenen eşya ya da yüzeyi hemen temizleyiniz.

-Yumuşak gözenekli yüzeyleri (hal1, perde, koltuk vb.) görünür bir kirlenme varsa deterjanla temizleyiniz. Mutlaka kurumasin sağlayınız.

- Havlu, çamaşır, çarşaf gibi tekstil ürünlerinin temizliğinde, öncelikle bu eşyaları silkelemeyiniz, bu eşyaları çamaşır makinesinde mümkün olan en sıcak isıda (en az 60 derecede) yıkayınız. Mutlaka kurumasını sağlayınız ve ütüleyiniz.

- Dışarıda kullandığınız kıyafetleri eve girmeden önce kapının dışında çıkarınız, dışarıdan içeriye ayakkabı sokmayınız. Bu kıyafetler konusunda üstünüze kullan-at şeklinde şeffaf yağmurluk vb. giysiler kullanabilirsiniz.

- Eğer hasta olan kişilerin eşyalarını yıkayacaksınız bu eşyaları bir eldivenle tutunuz ve ayrı olarak (mümkünse bir file içinde) mümkün olan en sicak isıda yıkayınız.

- Eldiveninizi çıkardıktan sonra da ellerinizi en az 20 sn süre ile su ve sabunla yıkayınız.

\section{TEMİZLIK/DEZENFEKSIYYN İçİN !!}

* Günlük ev temizliğinde çamaşır suyu çözeltisi kullanabilirsiniz.

\section{Çamaşır suyu çözeltisi hazırlamak için:}

3 litre suya 3 yemek kaşığı ya da bardağın 1/3'ü kadar çamaşır suyu

$\checkmark$ Ya da 1 litre suya 4 çay kaşığı çamaşır suyu ekleyerek elde edebilirsiniz. 


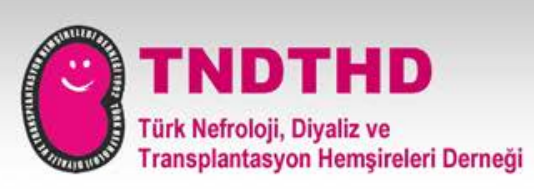

- Kullandığınız çamaşır suyunun (üretici firmanın) uygulama ve uygun havalandirma talimatına uyunuz.

- Kullandığınız ürünün son kullanma tarihini kontrol ediniz.

- Ev tipi çamaşır suyunu asla amonyak ya da başka bir hiçbir temizleyici ile karıştırmayınız.

- Alkol solüsyonu kullanacak iseniz; En az \%70 alkol içeren solüsyon ile kullandığınız yüzeyleri dezenfekte ediniz.

\section{ETRAFINIZDA HASTA BİRI VARSA !!}

- Etrafınızda hasta biri varsa mümkünse aynı evde yaşamayınız.

- Evinizi ayırmanız mümkün değilse;

$\checkmark$ Bu kişiler ile tuvalet, banyo ve yatak odanızı, havlu, fırça gibi ortak kullanılan malzemeleri ayırınız.

$\checkmark$ Hasta olan kişinin, evde sizden ayrı olarak farklı bir odada kalmasını sağlayınız.

$\checkmark$ Yiyeceklerinizi ayırınız.

$\checkmark \mathrm{Bu}$ kişilerin tabak, bardak, kaşık, çatal, bıçak gibi yemek yeme malzemelerini yıkarken bir eldiven kullanınız ya da bulaşık makineniz var ise makinede yıkayınız.

$\checkmark$ Hasta olan kişinin çöplerini ayrı bir torbada toplayınız.

$\checkmark \mathrm{Bu}$ çöpler de atılırken eldiven kullanınız ve çöp torbasının ağzını sıkıca kapatınız.

\section{YAPMANIZ GEREKEN DİĞER KORUYUCU ÖNLEMLER !!}

- Çiğ meyve ve sebze tüketmeyiniz, meyve ve sebzelerinizi yemeden önce çok iyi yıkayınız.

- Et ve et ürünlerini iyi pişiriniz. Çiğ olarak tüketmeyiniz.

- Dişardan gelen tüm malzemeleri buzdolabına ve raflara koymadan önce mutlaka su ve sabunlu bezle siliniz, poşetlerini atınız ve buzdolabına bu poşetlerle koymayınız. 


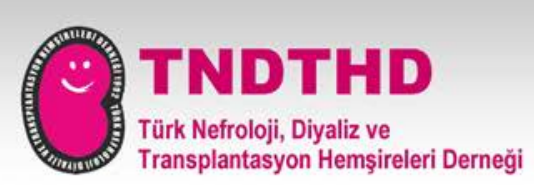

- Yanınızda en az iki haftalık ilacınızın olduğundan emin olunuz.

- İlaçlarınız için öncelikle eczanenizi arayınız.

- Eczacınıza kullandığınız ilaçlarınızın mevcut olup olmadığını sorunuz.

- İlaçlarınızı almak için kalabalık ortamlara girmeyiniz.

- Eczacınızdan ilaçları size ulaştırmasını talep edebilirsiniz ya da aile bireylerinizden gerekli önemleri alarak ilaçlarınızı eczaneden almasinı isteyebilirsiniz.

\section{BAĞIŞIKLIK SİSTEMINİİ GÜÇLENDİRMEK İÇİN NELER YAPABILIRSINİZ?}

- Düzenli uyuyunuz.

- Sağlıklı ve dengeli beslenmeye devam ediniz.

- Organ nakli ekibinizin size önerdiği miktarda su tüketiniz.

- Organ nakli ilaçlarınızı organ nakli ekibinizin önerdiği saat ve dozda almaya devam ediniz.!!

- Organ nakil ekibinize danışmadan destek hiç bir ilaç almayını.!!

\section{SIK SORULAN SORULAR}

\section{1) ORGAN NAKİL MERKEZLERINDE RUTİN KONTROLLERIMII NASIL YAPTIRMALIYIM?}

Her organ nakli bekleyen ya da organ nakli olmuş hastanın rutin kontrolleri vardır. Bu salgın hastalık sürecinde sizleri korumak için hastalığın bulaşması açısından riskli yerler olan hastanelere gitmeyiniz. 


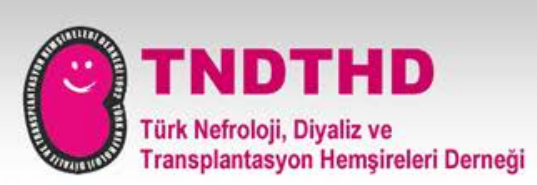

BU NEDENLE AŞAĞIDA Kİ HUSUSLARA DİKKAT EDİNİ;;

- Salgın öncesi zamanlarda size verilmiş olan kontrol randevusuna gidip gitmeyeceğiniz hakkında mutlaka merkezinizin organ nakil sorumlusunu arayınız.

- Organ nakli merkezinizle, rutin bakımınız konusunda telefonla danışmanlık alabilirsiniz.

- Hastalık belirtileri görüldüğünü düşünüyorsanız (yukarıda bilgi verilmiştir) mutlaka organ nakli merkezinizi arayınız.

- Ateş ya da nefes darlığı probleminiz varsa mutlaka organ nakil merkezinizi arayınız.

- Bir sağlık sorunu geliştiğini düşünüyorsanız mutlaka organ nakli merkezinizi arayınız.

- Nakil merkezinize bilgi vermeden bir sağlik kuruluşuna ya da kendi nakil merkezinize gitmeyiniz.

- Organ nakli merkezinizle görüşmeden herhangi bir sağlık kuruluşuna gitmeyiniz.!!

- Mesai saatleri dışında sizde bir sağlık sorunu oluştuysa 112'yi arayınız. 112 personelinden konu ile ilgili danışmanlık alınız.

\section{2) İLAÇLARIMDA HERHANGİ BİR DEĞİŞİKLIKK YAPMAM GEREKIR MI??}

\section{Organ nakli ekibinize danışmadan asla ilaçlarınızda değişiklik yapmayınız.!!}

İlaçlarınızı doğru şekilde kullanmanız hem organınızı korumanız hem de COVID-19 koronavirüs hastalığına karşı kendinizi korumanız açısından son derece önemlidir. 


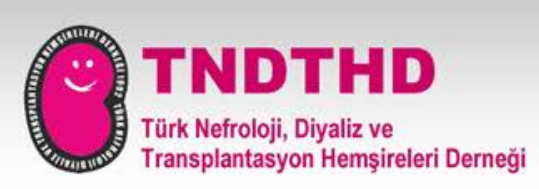

\section{Kaynaklar}

1. CDC-Centers of Disease Control and Prevention, Coronavirus Disease 2019 (COVID-19), Erişim: https://www.cdc.gov/

2. Transplantation Global Transplantation COVID Report, Erişim: www.tts.org/ txcovid19

3. ERA/EDTA COVID-19 guideline, Erişim: https://www.era-edta.org/en/ covid-19-news-and-information/

4. T.C. Sağlık Bakanlığı Halk Sağlığı Genel Müdürlüğü Yeni Koronavirüs Hastalığı (COVID-19), Erişim: https:/ / covid19bilgi.saglik.gov.tr/tr/

5. AST-American Society of Transplantation, Coronavirus disease 2019 (COVID-19): frequently asked questions from transplant candidates and recipients, Erişim: https://www.myast.org/coronavirus-disease-2019-covid19-frequently-asked-questions-transplant-candidates-andrecipients?utm_campaign=website\&utm_source=Weekly\%20Digest\&utm_me dium=EmailWHO-World\%20Health\%20Organization , www.who.int

6. WHO-World Health Organization, www.who.int. Erişim: https://www. who.int/images/default-source/health-topics/coronavirus/riskcommunications/hand-cleaning/handrub.jpg?sfvrsn=e9b44b62_2

7. https://covid19bilgi.saglik.gov.tr/depo/afisler/COVID19-TIBBI-MASKEKULLANIMI-29X20-2KIRIMLI-BROSUR.pdf.pdf Erişim Tarihi: 07.04.2020

8. ECDC REPORT Guidance for social distancing measures aimed at minimising the spread of SARS-CoV-2 23 March 2020, Erişim tarihi:07.04.2020 https://www.ecdc.europa.eu/sites/default/ files/documents/covid-19social-distancing-

9. AST.Power2Save one transplant for life. Coronavirus disease 2019 (COVID-19): FAQs for transplant candidates and recipients Erişimhttps://www.myast.org/ coronavirus-disease-2019-covid-19-frequently-asked-questions-transplantcandidates-and-recipients 
Karakoç ve ark.; Türk Nefroloji, Diyaliz ve Transplantasyon Hemşireleri Derneği COVID-19 Komisyonu COVID-19 Koronavirüs Hastalığı Rehberleri

\section{Kaynaklar}

1. WHO-World Health Organization, WHO Coronavirus Disease (COVID-19) Dashboard Erişim: https://covid19.who.int/

2. CDC-Centers of Disease Control and Prevention, Coronavirus Disease 2019 (COVID-19), Erişim: https://www.cdc.gov

3. Transplantation Global Transplantation COVID Report, Erişim: www.tts.org/txcovid19

4. The Transplant Society, COVID-19 Coronavirus Dashboard, Erişim: https:/tts.org/11-tts/news/692-tts-coronavirus

5. ERA/EDTA COVID-19 guideline, Erişim: https://www.era-edta.org/en/covid-19-news-and-information/

6. T.C. Sağlık Bakanlığı Halk Sağlı̆̆ı Genel Müdürlüğü Yeni Koronavirüs Hastalığı (COVID-19), Erişim: https://covid19bilgi.saglik.gov.tr/tr/

7. AST-American Society of Transplantation, Coronavirus disease 2019 (COVID-19): frequently asked questions from transplant candidates and recipients, Erişim: https://www.myast.org/coronavirus-disease-2019-covid-19-frequentlyasked-questions-transplantcandidates-and-recipients

8. https://covid19bilgi.saglik.gov.tr/depo/afisler/COVID19-TIBBI-MASKEKULLANIMI-29X20-2KIRIMLIBROSUR.pdf.pdf Erişim Tarihi: 07.04.2020

9. ECDC REPORT Guidance for social distancing measures aimed at minimising the spread of SARS-CoV-2 23 March 2020, Erişim tarihi:07.04.2020 https://www.ecdc.europa.eu/sites/default/files/documents/covid-19-social-distancing- 